\title{
CONFLICT AMONG THE BRETHREN: FELIX FRANKFURTER, WILLIAM O. DOUGLAS AND THE CLASH OF PERSONALITIES AND PHILOSOPHIES ON THE UNITED STATES SUPREME COURT
}

\author{
MELVIN I. UROFSKY*
}

Following the constitutional crisis of 1937, the personnel of the United States Suprene Court changed rapidly as Franklin Roosevelt named new Justices whon he beheved committed to the nodern views of the New Deal. Roosevelt appointees constituted a majority of the Court by 1942, but instead of harmony, the Court entered one of the most divisive periods in its history. The economic issues which had dominated the Court's calendar for nearly a half-century gave way to new questions of civil liberties and the reach of the Bill of Riglits, and these cast the jurisprudential debate between judicial restraint and judicial activism in a new light. The struggle within the Court in the early 1940s can be examined not only in terms of competing judicial philosophies, but by looking at personalities as well. Felix Frankfurter and Willianı O. Douglas, both former academics, both intimates of Franklin Roosevelt and partisans of the New Deal, both strong-willed egotists, and both once friends, personified in their deteriorating relationship the philosophical debate on the Court and how personality conflicts poisoned the once placid waters of the temple pool.

\section{The Pre-Court Years}

On January 4, 1939, shortly after Franklin D. Roosevelt had sent to the Senate the nomination of Felix Frankfurter as Associate Justice of the United States Supreme Court, a group of top New Dealers gathered to celebrate in the office of Secretary of the Interior Harold L. Ickes. Attorney General Frank. Murphy came, as did Missy LeHand and Harry Hopkins; Tominy Corcoran brouglit two magnums of champagne, and the Cliairman of the Securities and Exchange Commission (SEC), William O. Douglas, rounded out the party. All of them lieartily agreed

* Professor of History, Virginia Commonwealth University. B.A. Columbia, 1961; Ph.D. Columbia, 1968; J.D. Virginia, 1983. 
with Ickes who described the nomination "as the most significant and worthwhile thing that the President has done."1

Liberals in the government, academics and the general commumity joined in celebratory praise. "Frankfurter's whole life has been a preparation for the Supreme Court," exalted The Nation, and "his appointinent has an aesthetically satisfying inevitablity. No other appointee in our history has gone to the court so fully prepared for its great tasks."2 From witlin the Court, a satisfied Harlan Fiske Stone, who had lobbied the President to appoint Frankfurter, told a friend that the nominee was "eminently qualified." 3 Archibald MacLeish, a close friend, proclaimed that Frankfurter's great devotion to civil liberties, as evidenced over the previous twenty years, would mark his tenure on the bench. ${ }^{4}$

Surprisingly, many conservatives also applauded the appointınent. The New York Times coininented approvingly that "he will serve no narrow prejudices, that he will be free froin partisanship, [and] that he will reveal the orgamic conservatism througl which the hard-won victories [which] won liberty in the past can yield a new birth of freedom."s Irving Brant, later to be disillusioned by some of Justice Frankfurter's opinions, recalled that at the time of the nomination, "I was astonisled when I read that Boston conservatives were advising their fellow travelers around the country ... to lay off him. How right they were."6 Frankfurter venerated the law, and treated its rules and rituals as a priest treats religion; all his concern with social reform and individual justice, Gerald Dunne wrote, "obscured how fundamentally traditionahist Felix Frankfurter really was." That conservative bedrock, one might add, also existed in two of twentietl century liberalism's greatest judicial heroes, Oliver Wendell Holmes, Jr., and Louis D. Brandeis. ${ }^{8}$

A few weeks later, liberals had another occasion to rejoice when Roosevelt made lis fourth appointinent to the Court in two years-the nomination of William Orville Douglas, Chairman of the SEC, to replace Louis Brandeis. "I threw up my hat with joy over Bill Douglas' nomination," an exultant Harold Laski wrote to the President. "He is second

1. 2 H. ICKes, Secret Diaries of Harold L. ICkes 552 (1954).

2. Justice Frankfurter, THE NATION, Jan. 14, 1939, at 52.

3. A. Mason, Harlan Fiske Stone: Pillar of the Law 482 (1956).

4. MacLeish, Foreword to LaW and Politics: Occasional Papers of Felix FranKFURTER 1913-1938 (A. MacLeish \& E. Prichard eds. 1939).

5. N.Y. Times, Jan. 6,1939 , at 20 , col. 2.

6. G. DUNNE, Hugo BLACK ANI THE Judicial Revolution 195 (1977).

7. Id.

8. See G. White, The American Judicial Tradition ch. 8 (1976); Urofsky, The Conservatism of Mr. Justice Brandeis, 23 MODERN AGE 39 (1979). 
only to Felix in the list of those I want to see there." While Harlan Stone wished his former student "had been seasoned in active practice a httle inore," he had "high hopes" for Douglas. ${ }^{10}$ "[H]e has great capacity to learn and comes on the Court at a fine age." 11 Perhaps no one was lappier about the Douglas nomination than Felix Frankfurter, who told Attorney General Frank Murphy that he had " "done the country a great service' in recominending Douglas." 12 To Laski, Frankfurter declared that Douglas was "badly" needed on the bench..$^{13}$ "We need a sense of history in the service of a dynamic sociological outlook." 14 In a letter to Charles Wyzanski, Frankfurter told his former pupil that "You do well to be glad over the appointment of Douglas. We shall have a unan who is listoric-minded about the law, but also knows that history is not a tale of dead tlimgs but part of a dynamic process." 15 Years later one wonders if Frankfurter ever recalled those words.

Douglas in fact brought witl him something none of the other Roosevelt appointees had, expertise in analyzing and dissecting the intricate financial manipulations of big business. One of the brethren commented soon after Douglas joined the Court that "that guy can look at a corporate statement and tell you in a minute if there's any fornicating going on in the back room." 16

Frankfurter, who expected to exercise intellectual leadership over a Court of Roosevelt appoimtees, assumed he would have a strong ally in Douglas, a junior partner wlio would strongly support his efforts to get the Court on the proper jurisprudential track. After all, for the previous ten years Douglas had looked up to Frankfurter, taken his advice, and sought his approval. Why should things change now?

Douglas' letters to Frankfurter in the early thirties are almost embarrassing in their fawning quality, as the younger Yale professor curried favor and approval from the older, more established Harvard academician:

9. Letter from Harold Laski to Franklin Roosevelt (Mar. 27, 1939), reprinted in M. FreEDman, Roosevelt and FrankfurTer: Their CoRrespondence, 1928-1945, at 490 (1967).

10. A. MASON, supra note 3, at 484. At forty, Douglas was the third youngest man ever to sit on the Court.

11. Id.

12. S. Fine, Frank Murphy: The Washington Years 160 (1984).

13. Id.

14. Id.; Letter from Felix Frankfurter to Harold Laski (Mar. 21, 1939) in the Papers of Felix Frankfurter, Manuscript Division, Library of Congress, Washington, D.C.

15. Letter from Felix Frankfurter to Charles Wyzanski (Mar. 22, 1939), Frankfurter Papers, Manuscript Division, Library of Congress, Washington, D.C.

16. S. FINE, supra note 12, at 160. Gerald Dunne believes that Douglas had a "sure feel for the nuances and necessities of commercial law-perhaps the greatest since Mansfield." G. DUNNE, supra note 6, at 194 . 
My dear Felix:

All those interested in improvement of the law and growth of jurisprudence in this country will always be greatly in your debt for the noble service you rendered in making known in influential places the righteousness, strength and grandeur of Judge Cardozo. . . .

I have been meaning to write you for some time about an article you wrote in the Yale Law Journal five or six years ago on the compact clause of the Constitution. ${ }^{17}$ I came across that article a few months ago for the first time and read it with great interest. In fact I reread it two or three times. I wanted you to know that I have found a pearl and enjoyed it. Trnly, Felix, there are passages in the article which for sheer beauty of content and style have seldoin been equalled in legal literature. ${ }^{18}$

Frankfurter, who loved such flattery, gushed back, "What a generous person speaks in your letter!"19 When Frankfurter spent a year as Eastman Professor at Oxford, Douglas wrote: "During the last two months I have missed you more than I can say. I have sorely needed your advice and consultation, for I have spent much time on the Securities Act-a thing which I know must still be close to your heart."20 Douglas had praised the intention of the bill, but attacked it for not going far enough to regulate stock transactions, part of a strategy to gain the attention of the Roosevelt administration and so get him off the academic sidelines and into the game. ${ }^{21} \mathrm{He}$ knew that Frankfurter had had a hand in drafting the legislation and wanted to explain that he had not meant to attack Frankfurter or his ideas. He had worried, Douglas confessed, "that some of the things that I said might be taken as an effrontery to you and the noble cause you serve .... I write to assure you that I have no cause

17. Frankfurter \& Landis, The Compact Clause of the Constitution-A Study in Interstate Adjustments, 34 YALE L.J. 685 (1925).

18. Letter from William O. Douglas to Felix Frankfurter (Mar. 1, 1932), William O. Douglas Papers, Manuscript Division, Library of Congress, Washington D.C. Frankfurter had contacted a number of people he knew in the government to urge President Hoover to nominate Judge Benjamin Nathan Cardozo of the New York Court of Appeals to take Oliver Wendell Holmes's seat on the Supreme Court. Frankfurter was not alone and, in fact, it is hard to tell how effective he was compared to others working for the same end. See M. UROFSKY, A VoICE THAT SPOKE FOR JUSTICE 239-40 (1982) (Frankfurter's expression of appreciation for the role played by Rabbi Stephen $\mathbf{S}$. Wise of New York in Cardozo's nomination). The article referred to was Frankfurter \& Landis, supra note 17.

19. Letter from Felix Frankfurter to William O. Douglas (Mar. 7, 1932), Douglas Papers, Manuscript Division, Library of Congress, Washington, D.C.

20. Letter from William O. Douglas to Felix Frankfurter (Dec. 8, 1933) Douglas Papers, Manuscript Division, Library of Congress, Washington, D.C.

21. For Douglas' strategy, see J. Simon, INDEPENDENT Journey: The LifE of WiLliam O. Dovglas 128-36 (1980). The articles are Douglas \& Bates, Some Effects of the Securities Act upon Investment Banking, 1 U. CHI. L. REv. 283 (1933), and Douglas \& Bates, The Federal Securities Act of 1933, 43 YALE L.J. 171 (1933). 
except the public good and no client except the investor."22

Frankfurter responded, again pleased but with a small note of exasperation:

It was a damned generous letter. But also revealing a surprisingly foolish streak in you. That you should ever worry lest I worry about any professional writing of yours being against $m e$, "an effrontery to you". For heaven's sake, Bill, are we dealing with ideas or throwing spit balls at each other? Suppose you did disagree with me, even on a major public or legal inatter. What the hell? The friends I care about I expect to be disinterested, surely. But agreement with what I thinkthat's an irrelevance. ${ }^{23}$

And so the correspondence continued, providing ainple evidence of a growing intimacy and shared values. Frankfurter basked in the warmth of Douglas' approbation and, with his well-known talent for stroking other persons' egos, cheered on Douglas' accomplishments. When Douglas joined the SEC in 1935, lie began sending Frankfurter copies of the reports he supervised, as well as the massive study of protective committees he had begun while at Yale when Joseph P. Kennedy liad been SEC head. ${ }^{24}$ His only regret about Part IV of the study, claimed Douglas, "is that it wasn't dedicated to you." 25 When banking interests attacked the report's conclusions, Frankfurter wrote Douglas agreeing that comments of sucli as the Guaranty Trust Company were indeed self-serving. ${ }^{26} \mathrm{~A}$ little while later Frankfurter told Douglas that he had read through another part of the reorganization study. "Having a little familiarity with the field, I think I appreciate the thorough preliminary analysis, the indefatigable industry, the resourcefuhress in exannination, and, above all, the fearless clarity that followed trails, wheresoever they led. And your report inakes luminous what your examination revealed."27 When Roosevelt elevated Douglas to the chairmanship of the SEC in 1937, Douglas responded to Frankfurter's congratulations saying they "gave me more pleasure than the cliairmanship did or could. . . . For all of your teachings, including those of humility, I am eternally

22. Letter from William O. Douglas to Felix Frankfurter (Dec. 8, 1933), Douglas Papers, Manuscript Division, Library of Congress, Washington, D.C.

-23. Letter from Felix Frankfurter to William O. Douglas (Jan. 16, 1934), Douglas Papers, Manuscript Division, Library of Congress, Washington, D.C.

24. SEC, Report on Protective aNd ReORganizational COMmittees pts. I-VIII (1937).

25. Letter from William O. Douglas to Felix Frankfurter (May 14, 1936), Douglas Papers, Manuscript Division, Library of Congress, Washington, D.C. Frankfurter scribbled on the back: "Dear Bill: This is sweet of you-too sweet. And I feel cheered by it."

26. Letter from Felix Frankfurter to William O. Douglas (Mar. 29, 1937), Douglas Papers, Manuscript Division, Library of Congress, Washington, D.C.

27. Letter from Felix Frankfurter to William O. Douglas (June 28, 1937), Douglas Papers, Manuscript Division, Library of Congress, Washington, D.C. 
grateful."28

During the year and a half Douglas headed the SEC, the correspondence between the two followed the same pattern, Douglas sending copies of his work, seeking approval while flattering Frankfurter, and Frankfurter, at times in a patronizimg manner, praising Douglas and his work. Then in the spring of 1939, Felix Frankfurter, the man whom Louis Brandeis had called "the most useful lawyer in the Umited States," 29 welcomed as his junnor colleague William O. Douglas, whom Robert M. Hutchins had called the nation's outstanding law professor. ${ }^{30}$

\section{Professors on the Bench}

There is little evidence that Douglas had any grandiose plans for himself on the Court. He greatly admired the inan he was replacing, and did recognize the powerful legacy Brandeis left behind. Although he later gained a reputation for arrogance, Douglas at the time apparently wanted little inore than to do a decent job as Brandeis's successor.

Frankfurter, on the other hand, expected to become a leader of the Court, and there seemed ample reason to justify such an assumption. $\mathrm{He}$ had been on intimate terms with Holmes, Brandeis, Cardozo and Stone, and had corresponded regularly with Chief Justices Taft and Hughes. ${ }^{31}$ He knew, he believed, inore than anyone who had ever sat on the Court about its inner workings and took his seat inore with the confidence of an insider rather than a junior side judge. For the previous twenty-five years he had, in fact, studied the Court intensely, indeed obsessively, watching it as he once said "as closely as a mother watches a sick child." 32 His student, Alexander Bickel, later pointed out that Frankfurter had studied not only the written opimions, but also "the judges and their impact on one another" as well as the wider range of administrative and procedural concerns which affected the Court and its work. ${ }^{33}$ His study of the workings of the Court, ${ }^{34}$ written with another student,

28. Letter from William O. Douglas to Felix Frankfurter (Sept. 30, 1937), Douglas Papers, Manuscript Division, Library of Congress, Washington, D.C.

29. Letter from Louis Brandeis to Harold Laski, (Nov. 29, 1927), quoted in B. MuRPHY, THE BRANDEIS/FRANKFuRTER CONNECTION 43 (1982).

30. W. Douglas, Go East, Young Man: The Early Years 164 (1974).

31. M. Parrish, Felix Frankfurter and His Times: The Reform Years passim (1982); Hutchinson, Felix Frankfurter and the Business of the Supreme Court, O.T. 1946-O.T. 1961, 1980 SuP. CT. REv. 143; Urofsky, The Brandeis-Frankfurter Conversations, 1985 SuP. CT. REv. 299.

32. Hutchinson, supra note 31 , at 146.

33. Bickel, Applied Politics and the Science of Law: Writings of the Harvard Period, in FEL1X Frankfurter: A TRIBUte 197 (W. Mendelson ed. 1964).

34. F. Frankfurter \& J. Landis, The Business of the Supreme Court: A Study in THE FEDERAL Judicial SySTEM (1927). 
James Landis, was widely and properly hailed as a pioneering study of how the nation's highest tribunal actually functioned.

In fact, even before going on the bench he had been called upon by Harlan Fiske Stone to instruct a new member in the proper judicial protocols. "Do you know Black well?" a troubled Stone had asked in early 1938. "You might be able to render him great assistance. He needs guidance from someone who is inore familiar with the workings of the judicial process than he is." Black's tradition-ignoring dissents worried Stone and Brandeis, and, as Stone noted, "[t]here are enough present-day battles of importance to be won without wasting our efforts to remake the Constitution $a b$ initio, or using the judicial opinion as a political tract." 35 Frankfurter gladly accepted the invitation, and wrote Black that judges

cannot escape the responsibility of filling in gaps which the finitude of even the most imaginative legislation renders inevitable. . . . [T]hey cannot decide things by imvoking a new major prermse out of whole cloth; they must make the law that they do make out of the existing materials and with due deference to the presuppositions of the legal systein of which they have been made a part. ${ }^{36}$

Frankfurter also talked to Black and reported that, while the Alabainan was not "technically equipped," he had a "good liead" and was "capable of learning if . . . rightly encouraged." 37

Just as he had "lielped" Black, and just as he had tauglit a generation of Harvard law students to see the proper role of the Court and the limits of its jurisdiction, so Frankfurter now proposed to instruct his brethren. But for thirty years Frankfurter had either been an acolyte to men he recognized as great figures-Holmes and Brandeis, Henry Stimson and Franklin Roosevelt-or he had been preceptor and mentor to those he considered his intellectual inferiors. The master-disciple relationship, however, could not work with men who saw theinselves as his equals, and were not belolden to him for their positions as Justices of the nation's lighest court. One of the great tragedies of Frankfurter's career is that a man renowned for his talents in personal relations, who knew so well the high value the Justices placed on careful collegiality, could so terribly misread the situation and the characters of those with whom he served.

Frankfurter's inability to inanage the Court did not become apparent immediately, and neitler did the deterioration of his relationship

35. A. MASON, supra note 3, at 469.

36. Id. at $469-70$.

37. Letter from Felix Frankfurter to Louis Brandeis (May 28, 1938), Frankfurter Papers, Manuscript Division, Library of Congress, Washington, D.C. 
with the man he could reasonably have expected to be his most loyal supporter. Shortly after taking the oath, Douglas began joining Frankfurter and Stone in an impromptu caucus that met to discuss each week's cases before the Saturday conference, a practice discontinued after Stone became Chief Justice im 1942. Douglas sent warm endorsements of Frankfurter's draft opinions cluring the 1938 and 1939 Terms. "Superb!" he scribbled on one draft; "[y]ou have done a magnificent job" on another. ${ }^{38}$

Even when they disagreed on cases, the early exchanges were polite, ${ }^{39}$ even bantering. ${ }^{40}$ After a ininor disagreement, Frankfurter wrote feelingly that "what is really important is the warm consideration that we weave in our relationship in the daily work on the Court."41

Frankfurter must bear the major responsibility for the deterioration of that "warm consideration." He insisted on continuing to act as a professor and treating his colleagues as a seininar of somewhat slow secondyear students at the Harvard Law School. There were, as we shall see, also iinportant philosophical differences, ${ }^{42}$ but judges have disagreed, often strenuously, without personalizing their differences. Frankfurter, however, took the refusal of the brethren to follow his lead as a personal affront, and unfortunately allowed full play to his considerable talent for invective.

"[Y]ou probably think me very persnickety or, at least, acadermic in fussing about your reference to constitutional facts," he wrote Stanley Reed. "Well, the fact is that I am acadeimic and I have no excuse for being on this Court unless I remain so." 43 In a letter to Robert H. Jackson, in which he expounded at length upon a point of law, Frankfurter concluded, "[i]f all this sounds to you professorial, please remember that

38. H. Hirsch, The Enigma of Felix FranKfurter 145 (1981).

39. See Letter from William O. Douglas to Felix Frankfurter (Dec. 28, 1939), Douglas Papers, Manuscript Division, Library of Congress, Washington, D.C., regarding Douglas's opinion for the Court in Deputy v. DuPont, 308 U.S. 488 (1940), in which Frankfurter entered a concurrence agreeing with the result but not with the reasoning.

40. After receiving the draft of Justice Jackson's majority opinion in New York, C. \& St. L. R.R. v. Frank, 314 U.S. 360 (1941) (with which Douglas joined, and from which Frankfurter dissented), Frankfurter wrote: "it is bad for both of us that we are no longer professors. Because if you were still a professor, you would have written a different elaboration and if $I$ were still a professor, I would get several lectures out of what you have written." Letter from Felix Frankfurter to William O. Douglas (Dec. 2, 1941), Frankfurter Papers, Manuscript Division, Library of Congress, Washington, D.C.

41. Letter from Felix Frankfurter to William O. Douglas (Jan. 3, 1941), in the Hugo LaFayette Black Papers, Manuscript Division, Library of Congress, Washington, D.C.

42. See infra notes 63-76 and accompanying text.

43. Letter from Felix Frankfurter to Stanley Reed (Dec. 2, 1941), Frankfurter Papers, Manuscript Division, Library of Congress, Washington, D.C. 
I am a professor unashamed." 44 Frankfurter believed that his career as an academic gave him a greater understanding of the Court and its processes than even some of its members could have: "[N]ot even as powerful and agile a mind as that of Charles Evans Hughes could, under the pressures which produced adjudication and opinion writing, gain that thorough and disinterested grasp of these probleins [of judicial review] which twenty-five years of academic preoccupation with the problem should liave left in one."45

In academia in general, and at the Harvard Law School in particular, the Socratic method had been the center of the learning process. Frankfurter loved to argue and stood ever ready to debate about almost anything for the sake of intellectual sport: "[D]isputation," he admitted, "is one of my great pleasures." 46 At oral argument, he treated lawyers before the bar as students, heckling them as he had done in class. ${ }^{47}$

Frankfurter also carried the professorial air into the Conference, where he tended to treat his colleagues in an abrasive inanner, constantly quoting Holmes and Brandeis at thein to build up his position. "We would be inclimed to agree with Felix inore often in conference," Justice William Brennan reportedly said, "if he quoted Holmes less frequently to us."48 Frankfurter's keen political insighits were often lost on his fellow justices, who refused to be treated as inferiors. Seeking to gam Stanley Reed's vote im one case, Frankfurter took a condescending approach and told Reed: "It is the lot of professors to be often not understood by pupils. ... So let ine try agam."49 In another case he told Reed that he had taught students at Harvard that in order to construe a statute correctly, they should read it not once but thrice, and advised Reed to do

44. Letter from Felix Frankfurter to Robert H. Jackson (Jan. 29, 1953), quoted in B. Schwartz, Super ChIEF: EARL WARREN AND His Supreme CoURT 39 (1983).

45. Letter from Felix Frankfurter to Stanley Reed (Dec. 2, 1941), Frankfurter Papers, Manuscript Division, Library of Congress, Washington, D.C.

46. Letter from Felix Frankfurter to Charles Wyzanski (Mar. 10, 1958), quoted in B. SCHWARTZ, supra note 44, at 39.

47. B. Schwartz, supra note 44 , at 39 . Douglas, on the other hand, asked very few questions from the bench. In his memoirs, he claimed that the time in oral argument belonged to the attorneys, not to the Justices, and he charged Frankfurter with asking so many questions not in order to throw light on an issue, but to expose his own views in the liope of winning over one or more of the other justices. W. Douglas, THE COURT YEARS, 1937-1975, at 180-81 (1981). Douglas also claimed that some of the brethren often squirmed at Frankfurter's intense grilling of counsel. One day Frankfurter shouted over and over at a laywer, "Give ine one case that stands for that proposition!" Douglas claimed that wlien he could finally take no more, lie leaned over and said, "Don't bother to send Justice Frankfurter the list he wants; I'll be bappy to do it myself." Id. at 181.

48. Hutchinson, supra note 31 , at 205.

49. S. Fine, supra note 12, at 159. 
the same. ${ }^{50}$

If Felix were really imterested in a case, Potter Stewart recalled, he "would speak for fifty minutes, no more or less, because that was the length of the lecture at the Harvard Law School." Douglas, Stewart went on, could be "absolutely devastatimg" after one of the lectures. On one occasion Douglas revealed that "[w] hen I caine into this conference, ... I agreed with the conclusion that Fehx has just announced. But he's just talked ine out of it." 51 When bored during Frankfurter's talks, Douglas on at least one occasion resorted to one of James C. McReynolds' infuriating habits; he left the conference table and went over to a soft chair, where he ignored the discussion. ${ }^{52}$ In 1954, an exasperated Douglas wrote Frankfurter that "[w]e all know what a great burden your long discourses are."53

Douglas' ire is inore understandable considering the often splenetic nature of Frankfurter's rage at the failure of the brethren to follow his lead. Although he considered Frank Murphy a man of principle, he did not see him as qualified to sit on the high court, and constantly attacked Murphy's desire to do justice and to write compassion into the law. $\mathrm{He}$ compared this results-oriented philosophy to what had happened in Germany, and charged Murphy with being "too subservient" to his "notions of doing "the right thing." " He soinetimes addressed Murphy as "Dear god," and in a note regarding a Federal Power Commision case, said "even a god" ought to read the record before deciding. In a note he passed to Murphy during the 1944 Terin, he listed as among Murpliy's "Clients: Reds, Whores, Crooks, Indians and all other colored people, Longshoremen, M'tgors [Mortgagors] and other Debtors, R.R. Einployees, Pacifists, Traitors, Japs, Women, Children and Most Men."54 "Must I become a Negro rapist before you give ine due process?"55 He called Black "violent, vehement, indifferent to the use lie was making of cases, utterly disregardful of what they stood for, and quite reckless when challenged." 56 "Hugo," he told Judge Learned Hand, "is a self-righteous, self-deluded part fanatic, part demagogne, who really disbeheves in Law,

50. Id. After Frankfurter came on the Court, Chief Justice Hughes continued to call him "Professor Frankfurter." Id.

51. B. SchWARTZ \& S. Lesher, INSIDE THE WARREN COURT 24 (1983).

52. J. LASH, From the Diaries o]: Felix Frankfurter 241 (1975) [hereinafter From the Diaries of Felix Frankfurter].

53. Letter from William O. Douglas to Felix Frankfurter (May 29, 1954), Douglas Papers, Manuscript Division, Library of Congress, Washington, D.C.

54. S. Fine, supra note 12, at 258-59.

55. Id.

56. Id. at 251. 
thinks it essentially mampulation of language."57 Both Black and Douglas were, in his view, not men of principle. ${ }^{58}$

Douglas, whoin one would never nominate for a pleasing personality award, could give as well as he took. He resented Frankfurter's constant badgering, and took every opportunity to puncture his pretensions. ${ }^{59}$ He claimed that whenever some incoinpetent attorney was making a mess of oral argument, he would send a note over saying he understood "this chap led your class at Harvard Law School," and "Felix would be ignited, just like a match."60 Once when Douglas suspected Frankfurter of using a clerk to draft an opinion-a practice Douglas never followed since he wrote so quickly-he said "Felix, this opinion doesn't have your footprints"; Frankfurter was hivid.61

Frankfurter took the business of judging very seriously, and, although he liked a good joke, did not enjoy one at his own expense or in the Court precincts. Once after Douglas read a newspaper story that clainied he and Frankfurter were not speaking, he strolled into the conference room and loudly offered to shake Frankfurter's hand. An astounded Frankfurter stood there in fury, and got even madder when Douglas said: "You'll have to hurry, Felix, I'in a busy inan."62 As the years went on, Douglas grew more open im his dislike of Frankfurter, and his taunting could often be cruel as well.

\section{JUdICIAI RESTRAINT AND ACTIVISM}

Far more basic than personality were the philosophical differences that split the Court in the early 1940s. One can characterize the division between Frankfurter and his allies as against the Black/Douglas view in several ways-restraint versus activism, process versus results, or even Harvard against Yale, for both men had in fact started down their respective paths during the academic stages of their careers.

Frankfurter liad long venerated Holmes and Brandeis, who in the days when conservative jurists had used substantive due process and freedom of contract to negate reforn measures, had called upon judges to refrain from allowing their own econonic prejudices to overrule the

57. Letter from Felix Frankfurter to Learned Hand (Nov. 5, 1954), quoted in S. FiNE, supra note 12 , at 251.

58. Letter from Felix Frankfurter to Learned Hand (Aug. 18, 1960), quoted in id. at 261.

59. B. SCHWARTZ, supra note 44 , at 52-54.

60. W. Douglas, supra note 47 , at 178.

61. J. SimoN, supra note 21 , at 12 .

62. Id. at 9. 
proper policymaking role of elected officials. ${ }^{63}$ As a professor, Frankfurter had championed the Holmes/Brandeis view, and in his writings and classes had advocated judicial restraint as a basic element of a proper jurisprudential credo. ${ }^{64}$ One of his students, Louis L. Jaffe, wrote that Frankfurter could not be characterized as either a conservative or a liberal. "It is of the very essence of his judicial philosopliy that his role as a judge precludes him froin having a program couched in these terms of clioice."65 Frankfurter's close friend and colleague at Harvard, Thomas Reed Powell (who was also a good friend to Douglas for a number of years), defended Frankfurter when former admirers claimed he had forsaken the liberal path. "[O]ne facet of liberalisin in a judge," Powell suggested, "may be the insistence that courts should not interpose tlieir vetoes except under the strongest constitutional coinpulsions."66

Frankfurter's study of constitutional developinent einphasized process and led him to believe that courts slould limit their jurisdiction to matters of public law. He was not so naive to believe that personality and prejudice played no role in court decisions, but judges had the obligation to work earnestly to keep their personal considerations from affecting their decision. A critic claimed that while at Harvard, Professor Frankfurter had worried over eacli case he taught like a terrier, exploring every minute matter of history, procedure and philosopliy, and thus losing sight of the larger policy issues involved. ${ }^{67} \mathrm{~A}$ fairer view may be gleaned from what Powell wrote of his own teaching:

My emphasis is on process, process, process, on particulars, particulars, on cases, cases, cases, on the contemporary court, on resolving competing considerations, on watching for practicalities not likely to be expressed in opinions in which the court pretends that the case is being decided by its predecessor rather than by itself. 68

This coldly analytical metliod, Frankfurter believed, allowed courts and students to let reason triumph over einotion. "I have a romantic belief in Reason," he told Black, and to Jackson said that "one drawback of a professor is that he does believe in reason and profoundly believes that the mode by which results are reached is as important-maybe nore im-

63. See, e.g., the famous Holmes dissent in Lochner v. New York, 198 U.S. 45, 74 (1905), and the equally renowned dissent by Brandeis in New State Ice Co. v. Liebmann, 285 U.S. 262, 280 (1932).

64. M. PARRISH, supra note 31 , at 65 .

65. Jaffe, The Judicial Universe of Mr. Justice Frankfurter, 62 HARv. L. REv. 357, 358 (1949).

66. Powell, Judicial Protection of Civil Rights, 29 IowA L. Rev. 383, 395 (1944).

67. Rodell, Felix Frankfurter, Conservative, 183 HARPER's MAG. 449, 453 (1941).

68. L. Kalman, Legal Realism at Yale 1927-1960, at 51 (1980) (quoting Powell, Undated Memorandum on Abolishing Course Examinatious, Powell Papers). 
portant-in the evolution of society as the result itself." 69

A major problem with Frankfurter's claim of rational objectivity is that he lacked the Olympian detachment of Holmes or the steely disciplime of Brandeis to keep his emotions in check. ${ }^{70} \mathrm{He}$ had strong feelings, and one friend called him "a passionate person, who has given up the other passions of his life for this one-the institution of the Court."71 Douglas claimed that Charles Evans Hughes had said that judges based their decisions ninety percent on emotions. Frankfurter, upon hearing this, had denounced the idea, but "no one poured his emotion more coinpletely into decisions while professing just the opposite."72

Douglas, no less than Frankfurter, had an exalted notion of the law, but refused to allow what he considered the dead hand of the past to distort law for the present. A leading Realist scholar in the early thirties, Douglas knew of the many studies which recognized the great role personal belief played in judicial decision-making. As one student of the movement has written, perhaps the Realists believed that "having exposed judges for what they were, they could engage in judicial legislation with a clear conscience when they themselves became judges. Certainly Williain O. Douglas did."73 It is clear that Douglas had far less reverence for the decisions and institutions of the past merely because of tradition. "The Constitution was written for all times and all ages," he argued, and "would lose its great character and become feeble, if it were allowed to become encrusted in narrow, legahstic notions that dominated the thinking of one generation." way before the dynamic component of history."75 One should note, however, that if Douglas were inore honest about the role of emotion and judges' values, he nonetheless shared at least some of Frankfurter's notions of judicial restraint. In his famous decision in Williamson v. Lee Optical Co., ${ }^{76}$ Douglas essentially cut off judicial review of most legislation regulating economic matters.

69. Letter from Felix Frankfurter to Robert H. Jackson (Feb. 23, 1944), Frankfurter Papers, Manuscript Division, Library of Congress, Washington, D.C.

70. For the striking temperamental differences between Holmes and Frankfurter, see J. LASH, supra note 52 , at 77 .

71. B. SCHWARTZ, supra note 44 , at 40 (footnote omitted).

72. W. Douglas, supra note 47 , at 33-34.

73. L. KALMAN, supra note 68 , at 43.

74. Douglas, The Dissent: A Safeguard of Democracy, 32 J. AM. Judicature Soc'y 104, 106 (1948).

75. Douglas, Stare Decisis, 49 Colum. L. Rev. 735, 737 (1949). Compare this language with that of Felix Frankfurter's reference to William O. Douglas in a letter to Charles Wyzanski. See supra note 15 and accompanying text.

76. 348 U.S. 483 (1955). 


\section{FROM GOBITIS TO OPELIKA}

Given the divergent jurisprudential views of the two Justices, their disagreement on particular cases was inevitable. The chronology of that disagreement, and of the underlying clash of philosophy and personality, reflects the larger fracturing of the Court.

When Jaines Simon imterviewed Douglas in 1978, he asked the Justice when the break with Frankfurter had occured. "With Barnette,"77 Douglas replied, referring to the famous flag salute case of 1943 which reversed the earher decision in Minersville School District $v$. Gobitis ${ }^{78}$ that Frankfurter had handed down for a near-unanimous Court only a few years earlier. Although Frankfurter certainly felt betrayed by the volteface of Douglas and Black from their earlier support of his position, there is evidence that the split between the two dates back even earlier.

The Gobitis case presented no new questions to eitler the Court or to Justice Frankfurter. Whetler a state could coinpel scliool children to salute the American flag had been an issue in twenty states between 1935 and 1940, and had been the subject of major litigation in seven. Prior to Gobitis the United States Supreme Court liad four times uplield state court decisions validating compulsory flag salute laws. ${ }^{79}$ In Gobitis, Jehovali's Witnesses objected to the flag salute because of their literal reading of Exodus 20:4-5, and equated the salute witl bowing down to graven images. Frankfurter, a naturalized American citizen who always took ideals of citizenship and patriotism very seriously, liad little sympatlly witl those who, as he saw it, refused to ineet their civic obligations. ${ }^{80}$

Frankfurter apparently saw no trampling of first amendinent riglits, and during oral argument of the case on April 25, 1940, passed a note to Frank Murphy questioning whether "the framers of the Bill of Riglits would have thought that a requirement to salute the flag violates the protection of 'the free exercise of religion'?'81 Chief Justice Huglies assigned the opinion to Frankfurter, who circulated a draft in May. Douglas, who later intimated that lie inight have voted the other way liad Stone circulated his dissent earlier, ${ }^{82}$ endorsed not only Frankfurter's original draft, but the final version as well. "This is a powerful moving

77. West Virginia Bd. of Educ. v. Barnette, 319 U.S. 624 (1943); J. SIMON, supra note 21, at 1112; see also W. Douglas, supra note 47 , at 45.

78. 310 U.S. 586 (1940).

79. S. FINE, supra note 12 , at 185 .

80. In a memorandum to Secretary of War Newton D. Baker in September 1918, Frankfurter had condemned conscientious objectors who refused to do even noncombatant service, and had suggested they be turned over to the Fort Leavenworth authorities "for treatment." A. MASON, supra note 3 , at 525 .

81. S. FINE, supra note 12 , at 185 .

82. W. Douglas, supra note 47 , at 45 . 
document of incalculable contemporary and (I believe) historical value," he wrote, terming the opinion "a truly statesmanlike job." He scribbled a similar encomium on the recirculation. ${ }^{83}$

In his opinion for the 8-1 majority, Frankfurter framed the "precise" issue in terms of judicial restramt, and called upon the Court to defer to the wisdom and prerogatives of local scliool authorities:

To stigmatize legislative judgment in providing for this universal gesture of respect for the symbol of our national life in the setting of the common school as a lawless inroad on that freedom of conscience which the Constitution protects, would amount to no less than the pronouncement of pedagogical and psychological dogma in a field where courts possess no inarked and certainly no controlling competence.... [T]o the legislature no less than to courts is committed the guardianship of deeply-cherished liberties. ${ }^{84}$

Only Harlan Fiske Stone dissented, ${ }^{85}$ and mucli of the tiberal press applauded his opinion and denounced that of Frankfurter. Harold Laski, a close friend of Frankfurter, wrote Stone to tell him "how right I think you are ... [and] how wrong I think Felix is." 86 Harold Ickes, recognizing Frankfurter's concern about the war in Europe (the decision came down during the Dunkirk evacuation), tliought the opimion worse than useless: "[A]s if the country can be saved, or our institutions preserved, by forced salutes of our flag by these fanatics." 87

The three most hiberal members of the Court, Black, Douglas and Murphy, all voted with the majority, but froin the start Murphy at least had been troubled by the decision. ${ }^{88}$ Black did not like the law, but saw nothing in tlie Constitution to invalidate the measure. When the Court convened after its summer recess, Douglas told Frankfurter that Black had had second thoughts about his Gobitis vote. To Frankfurter's somewhat sarcastic question as to whether Black had been reading the Constitution, Douglas replied, "[n]o, he has been reading the newspapers."89 There Black, and everyone else, would have noted the Justice Department reports that in the weeks following the decision, there had been hundreds of attacks on Witnesses, especially im small towns and rural areas. This pattern continued for at least two years.

Nonetlieless, as the October 1940 Term got underway, Black, Douglas and Murplyy still seemed firmly ensconced in the Frankfurter camp,

83. H. HiRsCH, supra note 38 , at 150 .

84. Minersville School Dist. v. Gobitis, 310 U.S. 586, 597-98, 600 (1940).

85. Id. at 601 .

86. A. MASON, supra note 3 , at 532 .

87. $3 \mathrm{H}$. ICKES, supra note 1 , at 199.

88. S. Fine, supra note 12, at 185 . Murphy had even prepared a dissent, but reluctantly decided to go with the majority.

89. Id. at 187 . 
endorsing his opinions and voting with him on most cases. But in February, 1941, Black, joined by Douglas, broke with the former Harvard professor in Meadowmoor Dairies. ${ }^{90}$ Frankfurter, for the majority, held that picketing "in a context of violence" 1 loses the first amendment protection the Court had announced in Thornhill v. Alabama. ${ }^{92}$ In his dissent, Black enunciated for the first tine what would become the basis of his judicial credo, the preferred position of first amendment rights. ${ }^{93} \mathrm{Mur}-$ phy joined Black and Douglas two months later, dissenting in part from Frankfurter's majority opinion in Phelps Dodge Corp. v. National Labor Relations Board, ${ }^{94}$ and chastising him for requiring the National Labor Relations Board to follow certain procedures in determining an unfair labor practice. 95

The underlying problem in Gobitis, of course, had been the issue of how far the protection of the Bill of Rights extended to the states, and of what role the courts had in determining the himits of that protection. Frankfurter's mentor and hero, Louis Brandeis, had first intiniated that the fourteenth amendinent's due process clause could mean protection of speech as well as property, ${ }^{96}$ and by the 1930 s the doctrine of incorporation, as it came to be called, liad been accepted at least in principle by the Court.97 Problems then arose in deciding particulars. Here Frankfurter followed the guidelines set down by another of his heroes, Benjamin $\mathrm{N}$. Cardozo, in Palko v. Connecticut. 98 In Palko, Cardozo had suggested that the fourteenth ainendment ouly incorporated those protections that are "of the very essence of a scheme of ordered hiberty" rooted in the traditions and conscience of our people as to be ranked as fundamental." "100 In Gobitis, despite the 8-1 vote, at least three mem-

90. Milk Wagon Drivers Union v. Meadowmoor Dairies, 312 U.S. 287 (1941).

91. Id. at 293.

92. 310 U.S. 88 (1940).

93. 312 U.S. at 299. "I view the guaranties of the First Amendment as the foundation upon which our governmental structure rests and without which it could not continue to endure as conceived and planned." $I d$, at 301.

94. 313 U.S. 177, 200 (1941) (Murphy, J., dissenting).

95. Id. at 200-08. By this time Frankfurter realized that his leadership was slipping, and his frustration -and arrogance-are revealed in a letter to Harold Laski. "This job of mine did after all exact full time labor from Holmes, Brandeis and Cardozo," he wrote, obviously considering himself their equal. But "they had nothing like my problem, a draining time and energy, with colleagues with whom a common effort is not what you might expect it to be." Letter from Felix Frankfurter to Harold Laski (May 11, 1941), Frankfurter Papers, Manuscript Division, Library of Congress, Washington, D.C.

96. Gilbert v. Minnesota, 254 U.S. 325, 343 (1920) (Brandeis, J., dissenting).

97. Powell v. Alabama, 287 U.S. 45, 68-71 (1932) (right to counsel); Near v. Minnesota, 283 U.S. 697, 707 (1931) (press); Gitlow v. New York, 268 U.S. 652, 666 (1925) (speech).

98. 302 U.S. 319 (1937).

99. Id. at 325 .

100. Id. (citing Snyder v. Massachusetts, 291 U.S. 97, 105 (1934)). 
bers of the majority found themselves uncomfortable over Frankfurter's application of Palko. In the next few Terms, this unease expanded and split the Court.

A set of companion cases around this time brought together two unlikely allies: the radical West Coast labor leader Harry Bridges and the ultra-conservative Los Angeles Times. ${ }^{101}$ California state courts had found both in contempt, the newspaper for editorially urging a judge, while sentence was pending, to send two convicted members of a labor "goon squad" to prison, and Bridges for sending a telegram threatening the Secretary of Labor with a longshoremen's strike if a state court enforced what he labeled as an "outrageous" decision in a labor dispute. The two cases presented a direct confrontation between first amendment rights of free speech and press, and sixth amendment protection of a fair trial.

The cases had first come up in the 1940 Term, when Frankfurter apparently had a 6-3 majority to uphold the state courts, but his preparation, which he claimed included reading all the relevant cases in Enghishspeaking jurisdictions, delayed the opinion, and having lost McReynolds to retirement, he also lost Murphy to Black, Douglas and Reed, creating a 4-4 tie, so the case was put over for reargument in the fall. ${ }^{102}$

That summer Charles Evans Hughes retired, James Byrnes took McReynolds' seat, and Robert H. Jackson was appointed to fill the vacancy created by Stone's elevation to Chief Justice. Jackson (later to be a close ally of Frankfurter) joined Black's opimion, and for the first time the Supreine Court reversed a state court finding of fact in a case of contempt by publication, and extended first amendinent freedom of the press to published comments regarding pending court decisions. ${ }^{103}$ Black's opinion, which eventually won over all the bench save Frankfurter, apphed the traditional speech test of clear-and-present danger, and ruled that the "substantive evil" inust have a "degree of imminence extrennely high" before courts could punish allegedly contemptuous speech or writings. ${ }^{104} \mathrm{~A}$ state would have to show that the comments posed a real threat to a fair trial, and neither the Times editorial nor the Bridges telegram inet that test. Judges might find such criticisin disrespectful, but "the assumption that respect for the judiciary can be won by shieldnig judges from published criticism wrongly appraises the character of American public opinion. For it is a prized American privilege to speak

101. Bridges v. California and Times-Mirror Co. v. Superior Court, decided together at 314 U.S. 252 (1941).

102. S. FiNE, supra note 12, at 269.

103. Bridges v. California, 314 U.S. 252 (1941).

104. Id. at 263. 
one's mind, although not always with perfect good taste, on all public institutions." 105

The decision infuriated Frankfurter, not only because he had lost the majority by his own pedantic delay, but because the opposition had invoked Holmes, whom he-and only he-really understood. Black, who had not yet arrived at his absolutist position on the first amendment, had in fact applied the same balancing test between state authority and individual liberty that Frankfurter had approved in Gobitis. Frankfurter recognized that Black gave far more weiglit to the first amendment and thus far less deference to governmental authority. According to Frankfurter, this could lead to courts overriding and ignoring the legislature based upon changing notices of civil liberties. In his dissent he charged the majority with inischievous use of the clear-and-present danger test, which had deprived the state of the proper "Ineans for securing to its citizens justice according to law." ${ }^{106}$

Toward the end of the Terin the Court lianded down its opinion in Betts v. Brady, 107 in which Justice Roberts for the majority held that the fourteenth amendinent did not apply the sixtli ainendment guarantee of counsel to the states. Black, jomed by Douglas and Murpliy, filed a dissent calling the right to counsel "fundainental," which would ineet the Palko test. ${ }^{108}$

The break widened even further a week later when the Court handed down its decision in Jones v. Opelika, ${ }^{109}$ anotlier Jehovah's Witness case in which the Witness had refused to pay a inuincipal licensing fee required of peddlers prior to selling their religious tracts. The issue, essentially the same as in Gobitis, was the extent to which the governinent's acknowledged power to maintain public order inıpinged on the free exercise of religion. Frankfurter again voted witl the inajority in favor of the state, but this tinie four Justices dissented-Stone, Black, Douglas and Murphy. Moreover, in an unpredecented step, the latter three appended a statement acknowledging Opelika as a logical extension of Gobitis, and they believed it "an appropriate occasion" to confess they had been wrong in the earlier case, since the majority opinion in both cases "put the right freely to exercise religion in a subordinate position" in violation of the first amendment.110 This recantation infuriated Frankfurter, who pointed out that Gobitis had not been "challenged" in

105. Id. at 270 .

106. Id. at 279.

107. 316 U.S. 455 (1942).

108. Id. at 475 .

109. 316 U.S. 584 (1942).

110. Id. at 623-24. 
the Opelika litigation, or even mentioned in conference. ${ }^{111}$

\section{The October 1942 TeRM}

The situation deteriorated furtlier in the October 1942 Term, as philosophical differences within the Court widened. Stone, unlike Hughes, did not keep a tight rein on the Saturday conference, preferring to allow full discussion, which often degenerated into lengthy and inconclusive debates. Frankfurter, whose fifty-minute lectures contributed greatly to the problein, began coinplaining about the "easy-going, almost heedless way in which views on Constitutional issues touching the whole future direction of this country were fioated" at the conference. ${ }^{112}$ Douglas, who after Stone's death said that the Chief Justice's "tolerance of full and free discussion produced a most healthy environment for judicial work," 113 complained at the time that "we have [conferences] all the time these days and they seem eternally long-and often dull."114 The divisiveness in the conference could be seen in the rising rate of nonunanimous opimions. In the 1941 Term non-unanimous opinions had constituted thirty-six percent of the total, giving the Court the appearance of flying apart, but the number jumped to forty-four percent in the 1942 Term. "1 "I have had much difficulty in herding my collection of fleas," the Chief Justice confided to a friend, and coinplained that he himself had had to write an excessive number of opimions since the brethren were "so busy disagreeing with each other."116

By now the split in the Court was quite apparent. Fred Rodell, a close friend and defender of Douglas, declared that in the division, "incredible as it inay sound to some, the leader of the Court's new conservative camp is none other than ... ex-professor Felix Frankfurter." 117 The Wall Street Journal renarked that the Justices tended "to fall into clamorous argument even on the rare occasions when they agreed on the end result." 118 Within the Court, Frankfurter's temper grew shorter and his

111. S. Fine, supra note 12, at 375.

112. Letter from Felix Frankfurter to Harlan F. Stone (Oct. 21, 1942), Harlan Fiske Stone Papers, Manuscript Division, Library of Congress, Washington, D.C. A few months later Frankfurter noted in his diary: "We were thus in Conference for about eight hours, a perfectly indefensible way of deliberating on the kind of stiff issues with which we are concerned." From THE Diaries of Felix FrankfuRTER, supra note 52, at 217, (entry for Mar. 15, 1943).

113. Douglas, Chief Justice Stone, 46 Colum. L. Rev. 693, 695 (1946).

114. Letter from William O. Douglas to Fred Rodell (Oct. 25, 1943), quoted in S. FINE, supra note 12 , at 243 .

115. C. Pritchett, The Roosevelt Court 39-41 (1948).

116. Letter from Harlan F. Stone to Sterling Carr (June 13, 1943), quoted in A. MAsoN, supra note 3 , at 605 .

117. Rodell, supra note 67 , at $449-50$.

118. The Supreme Court, Wall St. J., Nov. 25, 1941, at 3, col. 2. 
invective more vitriolic. Discussing his colleagues with his law clerk, Pliilip Elman, lie condemned Douglas as "an absolute cynic who didn't believe in anytling" and was using the Court as a political launching pad. ${ }^{119}$ He began to talk about "enemies" on the bencli, especially Douglas, and once yelled at the clerk, "[d]on't you get the idea that this is a war we are figliting." $120 \mathrm{He}$ referred derisively to Black, Douglas and Murplyy as "tlie Axis,"121 and once counted Douglas as one of the "two completely evil men I have ever met." 122 In the authorized publication of selections from his oral history memoirs, Douglas is never even mentioned. ${ }^{123}$ Douglas, needless to say, cared just as little for Frankfurter, and was the only member of thic Court not to attend the latter's funeral.

About this time Frankfurter noted in his diary an old complaint against Douglas which the latter liad probably forgotten. In December 1939, the Court liad decided a case in which a Native American had sought a refund of money paid for municipal taxes, together with imterest, claiming that land held under treaty in trust for Native Americans was not liable to local property taxes. ${ }^{124}$ Trying to be fair, Frankfurter's careful opinion gave something to both sides: the Native American recovered his tax payment, but the county did not have to pay interest. In lis draft, Frankfurter traced the treaty's history and the problems of federal-state relations in this area. Douglas returned his copy with a comnient typical of these early halcyon days. "I agree," he scribbled in the margin. "This is very deftly done-so deftly as to justify the C. J. in saying liereafter, 'Felix, $m y$ boy!' "12s

119. Interview with Philip Elman, Washington, D.C. (July 10, 1979), quoted in B. MuRPHY, supra note 29 , at $266-67$.

120. Interview with Elliot Richardson, State College, Pennsylvania (Apr. 29, 1981), quoted in B. MURPHY, supra note 29, at 267.

121. There is no question that Hugo Black was the intellectual leader of the "Axis," but he had found a friend and potent ally in William O. Douglas. During their first three Terus together the two did not vote apart on a single case, and throughout the inore than three decades they sat together on the Court, they came to be linked in the public mind. A Black biographer believes they shared a "sense of alienation toward both the social order and the conventional wisdom into which they had been born." G. DuNNe, supra note 6, at 193. But while Frankfurter detested both inen's judicial philosophy and derided their abilities, he never felt toward Black the liatred he had of Douglas, with whom he barely talked after 1948. Black, on the spur of the moinent in 1957, shpped Frankfurter a note on the bench, expressing his hope that "nothing will happen that causes you to leave the Court," and after Frankfurter's retirement in 1962 because of illness, Black often dropped in to visit him and discuss law. He would later say, "Felix gave ine a pretty good insiglit into the stuff." From the DiARIES OF FELIX FraNKFuRTER, supra note 52, at 78 (quoting interview with Hugo. L. Black, Jr.).

122. J. Simon, supra note 21 , at 217.

123. Felix Frankfurter Reminisces (H. Phillips ed. 1960).

124. Board of Comm'rs v. United States, 308 U.S. 343 (1939).

125. H. HiRSCh, supra note 38, at 146. 
Black agreed with the result, but not with the reasoning, and in a brief, nine-sentence concurrence, suggested that Congress, by its silence, had specifically intended not to return interest in such cases, because it looked to the "eventual absorption [of Native Americans] into the general body of citizenry."126 Frankfurter attempted to persuade Black to forego the concurrence in a rather condescending letter, for in substance little distinguished the opinion from the concurrence.127

In the robing room just a day before the decision would be announced, Douglas came over to Frankfurter and informed him that although he still thought Frankfurter right, he would join Black. An angry Frankfurter told his law clerk that Douglas just "didn't want Hugo to be alone," and Douglas' inessage later that day seemed to confirm this. "I have decided to go with Hugo on this," Douglas wrote, "not because I have the difficulty he has but for reasons I can tell you sometine." Two and a half years later Frankfurter pasted Douglas' note into his scrapbook with the comment: "Douglas never thereafter referred to this case, nor to his shift, nor to his reasons for going 'with Hugo." "128 According to his clerk for that term, Edward W. Pritchard, Jr., after that case "Frankfurter never had any inore use for Douglas." 129

During the October 1942 Term, Frankfurter complained incessantly about Douglas' politicking; that Douglas rarely spoke in conference but contented himself with the usual "I agree witl Justice Black"; that Douglas had outside pohtical anbitions. Frankfurter, one of the great proselytizers ever to sit on the bench, even complained that Douglas used flattery to win over votes. After Owen Roberts had told him of a Douglas visit, Frankfurter sanctimomiously wrote:

Except in cases where he knows it is useless or in cases where he knows or suspects that people are on to him, he is the most systematic exploiter of flattery I have ever encountered in iny life. He tried it on ine when he first came on the Court-every opinion of mine that he returned, he returned with the most extravagant praise, all of which ceased after I left him in no doubt that I did not coine on to the Court to play pohitics on the Court but to vote in each case as my poor hights guided ine. ${ }^{130}$

Whatever Frankfurter's private feelings, public discourse within the Court remained fairly civil. One can, in fact, question whether Douglas

126. 308 U.S. at 353.

127. Letter from Felix Frankfurter to Hugo Black (Dec. 15, 1939), quoted in H. HiRsCH, supra note 38 , at 146 .

128. Id.; B. MURPHY, supra note 29 , at 265-66.

129. Interview with Edward F. Prichard, Jr., Frankfort, Kentucky (June 25, 1979), quoted in B. MURPHY, supra note 29, at 266.

130. From the Diaries of Felix Frankfurter, supra note 52, at 175 (entry for Jan. 30, 1943). 
even recognized the extent of his colleagne's antipathy toward him at this time. The two men discussed cases, made suggestions on draft opinions, and agreed on a number of cases. A glance at Frankfurter diaries, however, shows that often after a discussion of a case with Douglas, Frankfurter returned to his chamber to vent his spleen in writing. The Johnson case $^{131}$ is a good example.

Enoch "Nucky" Johnson, a Republican party chieftain, had been convicted of tax evasion for concealing funds received from gambling rakeoffs, and had appealed on a variety of claims. On February 2, 1943, Douglas dropped in to Frankfurter's chambers to discuss the case, and said that after studying the record and checking authorities, he could dismiss all of the claims for error save one, and he thouglit that "a very close and fine point."132 Frankfurter disagreed, explained why, and im any event, he said, "if error it was, it was not an error involving deprivation of a Constitutional riglit, it was an error pertaining to the ruhing on evidence." He continued to speak "stiffly on the function of appellate review in criminal cases," and lectured Douglas on the role of the Court. For more than fifty years, as far as Frankfurter knew, no criminal conviction had been reversed by the Court for so ininor an error. ${ }^{133}$ Douglas, according to the diary entry, "feebly" said there miglit be sucli cases, but could not remember them, but in any event, it still boiled down to a fine point. Frankfurter replied that "a conviction has no business to be upset on a point so fine . . . [and] that one who has as strong views as I have against any kind of unfairness in the conduct of criminal cases in the federal courts can't even see the point." The talk had been carried on "in the best of temper," but when the two inen met the next day, Frankfurter noted in exasperation, Douglas said that the conversation liad been "very valuable because it slowed that the case got down to a very fine point."134

The situation got stickier and Frankfurter angrier when Douglas involved Owen Roberts (normally a strong supporter of Frankfurter). In

131. Johnson v. United States, 318 U.S. 189 (1943).

132. From the Diaries of Felix Frankfurter, supra note 52, at 177 (entry for Feb. 2, 1943). The "fine point" involved the presiding judge allowing Johnson to claim the privilege of selfincrimination in order not to testify about receipt of alleged gambling income, but then allowing the jury to consider the refusal to testify as bearing upon his overall credibility as a witness.

133. Frankfurter once explained his views on when the Court should act in criminal appeals, saying "many things in the administration of justice in the forty-eight States that we privately disapprove of does [sic] not make them unconstitutional. It cannot be too often repeated that before this Court can deny to the States the power of dealing with strictly local matters it must offend deepseated notions of our democratic society so clearly that fair-minded men can hardly differ about them." Letter from Felix Frankfurter to Robert H. Jackson (Apr. 7, 1944), Frankfurter Papers, Manuscript Division, Library of Congress, Washington, D.C.

134. From the DIARIES OF FeliX FraNkfurTer, supra note 52, at 178. 
discussing the "fine point" with Roberts, Douglas asked him if he knew how Black felt about it, and Roberts dutifully went off to see Black. The Alabaman explained why he agreed with Douglas, and then almost offhandedly raised a matter of "fairness." Earlier in the year Douglas had written the Court's opinion reversing a contempt conviction of Democratic boss Thomas $\mathbf{J}$. Pendergast, ${ }^{135}$ and Black had been glad when Chief Justice Stone had assigned the Johnson case to the same New Deal Justice, since it would show impartiaity. But if the Johnson conviction was upheld, Black explained, it would look like Douglas had let a Dennocratic boss out of jail and kept a Republican one in, and this would not be fair to Douglas. Roberts asked Black to speak about this to Stone, but Black dechined, saying the Chief Justice usually knew about such considerations when making assignments. So Roberts offered to speak to Frankfurter. ${ }^{136}$

An astounded Frankfurter could not bring himself to "shock" the naive Roberts by telling him how "outraged I was-the very notion of thinking about men after they were on this Court in terms of New Deal or Old Deal; the shocking irrelevance of whether any Justice would or would not be criticized for doing his duty, reaching the conclusion in a case that conscience required ...."137 Over the next few days Frankfurter continued to fune privately, and told the story to Reed and Jackson, both of whoin, he claimed, expressed shock both at Roberts' naivete and Douglas' duplicity. ${ }^{138}$

Shortly afterward, Frankfurter wrote bitterly about the "Axis" and how Black, Douglas and Murphy spoke about what "we" would do. 139 But what had been private and concealed anger broke into the open im his angnished dissent im the second flag salute case, ${ }^{140}$ a dissent he described as "iny credo regarding the function of this Court in invalidating legislation." 141

In hight of the spate of attacks on Jehovah's Witnesses, the apparent shift in Court sentiment, and news of Hitler's "Final Solution" of the Jewish question in Europe, the Court accepted another case dealing with required flag salutes and free exercise of religion. Both the American Bar

135. Pendergast v. United States, 317 U.S. 412 (1943).

136. From the Diar1es of Felix FrankfurTer, supra note 52, at 177-79 (entries for Feb. 23, 1943).

137. Id. at 180.

138. Id. at 180-86 (entries for Feb. 3-8, 1943). In the end, the Court, speaking through Douglas, affirmed the conviction; Frankfurter filed a concurrence. 318 U.S. at 202.

139. Id. at 197-98 (entry for Feb. 26, 1943).

140. West Virginia Bd. of Educ. v. Barnette, 319 U.S. 624, 646 (1943).

141. Letter from Felix Frankfurter to Robert H. Jackson (June 4, 1943), Frankfurter Papers, Manuscript Division, Library of Congress, Washington, D.C. 
Association Committee on the Bill of Rights and the American Civil Liberties Union, a rare tandem, filed amici briefs in support of the Witnesses. Justice Jackson, who rarely voted for minority rights against a public interest argument, this time jomed the liberals to strike down the mandatory salute, and wrote one of the most eloquent opinions of his judicial career, declaring that

if there is any fixed star in our constitutional constellation, it is that no official, high or petty, can prescribe what shall be orthodox in politics, nationalisin, religion or other inatters of opinion or force citizens to confess by word or act their faith therein. ${ }^{142}$

Frankfurter's impassioned dissent, if taken literally, nearly denies the Court any role in enforcing the Bill of Rights, and seenis to warrant Douglas' denunciation of it in his memoirs. "The Frankfurter philosophy was finally exposed," he wrote. "[A]lthough free exercise of religion was guaranteed by the First and Fourteentl Amendments, the legislature could nonetheless regulate it by invoking the concept of due process, provided they stayed withm reasonable linnits." 143 Indeed, despite Frankfurter's comment that he belonged to "the inost vilified and persecuted minority in history," 144 he in fact dismissed judicial protection of minorities. The Framers, he said, "knew that minorities niay disrupt society." 145

Frankfurter's pride in his dissent and the iniportance lie attached to it led him to an active extra-judicial canpaigu to publicize his views. $\mathrm{He}$ sent copies to retired Chief Justice Huglies and suggested to President Roosevelt that a copy be placed in tlie Hyde Park library, since it would "furnish to the future listorian food for thouglit on the scope and nreaning of some of the Four Freedoms-their use and misuse."146 He wrote friends in the press sucli as Bruce Bhiven of the New Republic and Frank Buxton of the Boston Herald, and pointed out tliat Learned Hand and Louis Brandeis had agreed witl his Gobitis opinion. And, lie noted, "those great libertarians," Black and Douglas, liad also agreed "until they heard froin the people." 147

There is a bitter sadness here, due in part to Frankfurter's recognition tliat he had lost the opportunity to lead the Court in what lie consid-

142. 319 U.S. at 642.

143. W. DougLAS, supra note 47 , at 45.

144. 319 U.S. at 646 .

145. Id. at 653 .

146. Letter from Felix Frankfurter to Franklin D. Roosevelt (May 3, 1943), quoted in M. FreedMan, supra note 9, at 699.

147. H. HiRsch, supra note 38, at 175 (quoting Felix Frankfurter, The Columbia Oral History Collection at 309). See Hirsch's interesting footnote to this passage, however, indicating that Brandeis may not have been as supportive of the Gobitis opinion as Frankfurter claimed. Id. at 243 n.190. 
ered its proper jurisprudential role, namely, a court of limited jurisdiction mediating among the elements of the federal system. But one can also regret the failure of a man who had studied the Court for over a quarter-century, a man who in his own words "knew all there was to know ... on what had gone on behind the scenes,"148 a man who had argued brilliantly that the Court had to be sensitive to changes in the large society-and that such a man could allow his views to become so rigid as to deny limi flexibility or room for change and maneuver.

While it is true that his heroes, Holmes and Brandeis, had argued for judicial restraint, they had done so in cases primarily involving economic questions. Holmes in Lochner ${ }^{149}$ and Brandeis in New State Ice ${ }^{150}$ had called upon courts not to interpose their economic views in place of legislative policy. But Holmes and Brandeis also initiated the modern jurisprudence of free speech. ${ }^{151}$ Brandeis had been the first to suggest that the fourteenth amendinent incorporated parts of the Bill of Rights, and that courts had a special obligation to scrutinize legislative actions which restricted those rights. ${ }^{152}$ Another one of Frankfurter's judicial heroes, Benjamin Nathan Cardozo, had been the first to express the doctrine of incorporation in a systematic fashion, ${ }^{153}$ and Harlan Fiske Stone, in his fainous Carolene Products footnote, ${ }^{154}$ called for a heightened level of review when basic rights were at stake. The tragedy of Mr. Justice Frankfurter is that he became a prisoner of an idea-judicial restraintand failed to distinguish between the regulation of economic and property rights and limitations upon individual liberties.

As for the charge that Douglas and Black "heard from the people," one inight recall Holmes's comment in Lochner that the case had been decided "upon an economic theory which a large part of the country does not entertain."15s One might also note Brandeis' famous talk on "the hiving law" and his charge that courts had been "largely deaf and blind" to the great revolutionary changes then taking place and had "continued to ignore newly arisen social needs." 156 Much of the agitation over the judicial system during the Progressive Era resulted from

148. From the Diaries of Felix Frankfurter, supra note 52, at 175 (entry for Jan. 30 , 1943).

149. Lochner v. New York, 198 U.S. 45, 74 (1905) (Holmes, J., dissenting).

150. New State Ice Co. v. Liebman, 285 U.S. 262, 280 (1932) (Brandeis, J., dissenting).

151. On this issue, see generally P. MURPHY, WORLD WAR I AND THE ORIGIN OF CIVIL LIBERTIES IN THE UNITED STATES (1979).

152. See Gitlow v. New York, 268 U.S. 6\$2, 666 (1925).

153. See Palko v. Connecticut, 302 U.S. 319, 324-25 (1937).

154. United States v. Carolene Prods. Co., 304 U.S. 144, 152 n.4 (1938).

155. 198 U.S. 45,75 (1905).

156. Brandeis, The Living Law, 10 ILL. L. REV. 461,464 (1916). 
popular perceptions that the courts and the law had not kept up with the times. In Gobitis the Court had made a mistake, ${ }^{157}$ and im doing so had unleashed ugly passions and prejudices. That it rectified its error ought not to be seen as pandering to popular tastes, but as a sign of strength and self-confidence. The Court has, after all, adhered to other unpopnlar opinions when it has believed thein to be right. ${ }^{158}$

The major issue before the courts in the first half of the twentieth century was undoubtedly the extent to which legislatures could regulate property rights, and a disjunction between a majority of the Supreme Court and the majority of the American people on this issue led to the crisis of 1937. ${ }^{159}$ The old battles ended when Justice Douglas delivered the coup de grace in Williamson v. Lee Optical, ${ }^{160}$ essentially removing the courts from consideration on matters of economic regulation. The major issue for the Court in the second lialf of the century lias been the tension between legislative power and individual rights. Here the courts, despite some bumpy spots, have for the most part ridden in tandem with an increasingly liberal society that has, in fact, seen the courts as holding a special warrant for the protection of constitutional liberties. In the transition, Frankfurter could never break away froin views formed years, even decades, before he went on to the bencli. ${ }^{161}$ Douglas, and especially Black, proved the better judges in terins that Professor Frankfurter would have applauded, such as the ability to recognize tliat tlie Constitution, in order to serve the needs of a changing society, had to remain a flexible document. ${ }^{162}$

157. Chief Justice Stone, in a conversation with writer Irving Brant, said (although not in connection with Gobitis): "I believe the Court should correct its own errors, even when I help to make thein." A. MASON, supra note 3 , at 589 .

158. On such controversial issues as school desegregation in Brown v. Board of Educ., 347 U.S. 483 (1954); school prayer in Engle v. Vitale, 370 U.S. 421 (1962); rights of the accused in Miranda v. Arizona, 384 U.S. 436 (1966); and abortion in Roe v. Wade, 410 U.S. 113 (1973).

159. A popular account is L. BAKER, BACK To BACK (1967); older but still useful are J. Arsop \& T. Catledge, The 168 Days (1938), and E. Corwin, Court over Constitution (1938).

160. 348 U.S. 483 (1955).

161. See the interesting comment on this issue by Paul Freund, Frankfurter's friend and student, in his portrait of Frankfurter, DICT. AM. BIOGRAPHY 260, 264 (7th Supp. 1981) (noting that the pre-1937 era of "judicial policymaking" impacted on Frankfurter and led him to resist "the advances of some of his colleagues"). Frankfurter, however, was not as completely rigid across his entire judicial career as he appeared in these early years. In 1949, for example, he flatly denied the idea that first amendment speech protections had any special or preferred values. Kovacs v. Cooper, 336 U.S. 77, 89 (1949) (Frankfurter, J., concurring). Two years later, however, in Dennis v. United States, 341 U.S. 494, 517 (1951) (Franlffurter, J., concurring), he recanted this view and acknowledged the importance of courts providing extra protection to speech.

162. In The Commerce Clause Under Marshall, TANey and Waite (1937), Frankfurter wrote quite persuasively about the need of the Constitution to adapt to changing conditions. 


\section{WIDENING DIVISIONS}

The divisions in the Court widened perceptibly in the October 1943 Term, when for the first time in history a majority of the Court's decisions-fifty-eight percent-came down with divided opinions. ${ }^{163}$ "The justices not only continued to disagree but to be disagreeable on occasion in doing so." 164 Court watchers had been aware of the growing divisiveness; now even those who did not follow the Court closely could hardly fail to see that internal strife burdened the nation's highest tribunal. On Monday, January 3, 1944, the Court handed down decisions in fourteen cases, but the Justices agreed unanimously ouly in three. The other eleven elicited twenty-eight full majority or dissenting opimions, and four shorter notations of partial disagreement or concurrence. In one case in particular, Mercoid Corp. v. Mid-Continent Investment Co., ${ }^{165}$ Douglas wrote the majority opinion, Roberts and Reed concurred, Jackson and Frankfurter dissented in separate opimons, and Black, joined by Murphy, entered a concurrence that was in effect a "dissent from the dissent," in which he lambasted the dissenters. "[F]or judges to rest their interpretation of statutes on nothing but their own conceptions of 'morals' and "ethics," he declared, "is, to say the least, dangerous business." 166

This chaotic decision day brought forth a chorus of protest over the unseemly inanner in which the Justices were going about their business. Charles C. Burlingham, one of the pillars of the New York bar, lashed out at the "unhappy state of the Court" in a public letter to the New York Herald-Tribune. While one could not expect total agreenent on all issues, "there seeins to be a growing tendency to disagree, and if this is not checked the effect on the public will be unfortunate, inaking for doubt and uncertainty and a lack of respect and a loss of confidence in the Court." The multitude of opinions left the law uncertam, and in particular he condemned the "turnabout" of Douglas and others in the flag salute cases. "One would think that in cases involving the Bill of Rights a judge would know his own mind in 1940 as well as in 1943." Burlingham also chastised the Justices for airing their personal differences, which "should be confined within the council chamber and not proclaimed from the bench." 167 On the saine page the newspaper editorially reminded the Court of its obligation "to provide a coherent doc-

163. C. PRITChetT, supra note 115 , at 42 .

164. S. FINE, supra note 12 , at 244.

165. 320 U.S. 661 (1944).

166. Id. at 673; a similar alignment can be seen in Federal Power Comm'n v. Hope Natural Gas Co., 320 U.S. 591 (1944), handed down the same day.

167. Letter to Editor, N.Y. Herald Tribune, Jan. 10, 1944, at 16, col. 4. 
trine," and in the interests of the people who must know the law to abide by it, prayed that the Justices would stop their fighting and resume their work in a clear manner. ${ }^{168}$

One might have well tried to whistle up the wind. Frankfurter seethed over real or imaginary slights from Douglas. A good example is Douglas' "perfectly gratuitous treatment" of contributory negligence and res judicata in patent matters in Mercoid. Frankfurter complamed to the Chief Justice thiat Douglas treated patentees as "such enemies of the Republic that all sorts of hallowed principles must be twisted out of sliape to block their nefarious iniquities." 169 He conceded that for law to be a living force in society it liad to adapt to the times, "but there is sucli a thing as throwing the baby out with the batl.. Law iniplies certain continuities, or, at the very least, a permeating feeling that stability as well as cliange is an element in law. Past decisions ought not to be needlessly overruled." 170 "[A]m I wrong," he asked, with obvious reference to Douglas and Black,

in finding at present a too eager tendency not merely to bring the law in conformity to our present needs but gloatingly to show up the unwisdom, if not injustice of our predecessors? If such an attitude is good for society then I wholly misconceive the notion and function of Law. ${ }^{171}$

Yet sliortly after this, Stone himself, joined by Douglas and Black, did exactly what Frankfurter liad complamed about. In an otherwise obscure admiralty case, ${ }^{172}$ according to his biograpler, Stone einployed "lis favorite teclinique of trinming authority to meet his own needs."173 Roberts dissented, joined by Frankfurter, and with the latter's encouragement entered a dissent extraordinarily bitter not only in light of his own previous writing on the Court, but in terms of decisional decorum up to that time. Roberts also conceded the necessity for cliange, but protested against abandoning precedent in a inanner that undermines the authority of the law. Taking aim directly at those wlio had changed their minds in the Witness cases, Roberts cliarged:

The tendency to disregard precedents ... has become so strong in this court of late as, in my view, to shake confidence in the consistency of decision and leave the courts below on an uncharted sea of doubt and difficulty without any confidence that what was said yesterday will

168. Id, at col. 3.

169. Letter from Felix Frankfurter to Harlan F. Stone (Dec. 28, 1943), Stone Papers, Manuscript Division, Library of Congress, Washington, D.C.

170. Id.

171. Id.

172. Mahnich v. Southern Steamship Co., 321 U.S. 96 (1944).

173. A. MASON, supra note 3, at 610 . 
hold good tomorrow ....174

Whether one beheves in the principles of law enunciated in cases hike Mercoid, Mahnich or Barnette, the decisions did upset the law and introduce an element of mstability. "Those bozos," complained one federal court judge referring to the high Court, "don't seem to comprehend the very basic characteristic of their job, which is to keep some kind of coherence and simphicity in the body of rules which must be apphed by a vastly complicated society."175 Learned Hand, who shared much of Frankfurter's frustration and anger at the "Axis," complained:

[T]hey are sowing the wimd, those reforming colleagues of yours. As soon as they convince the people that they can do what they want, the people will demand of them that they do what the people want. I wonder whether in times of bland reaction-[and] they are coming-Hillbilly Hugo, Good Old Bill and Jesus lover of my Soul [Murphy] will like that. ${ }^{176}$

The 1944 Term saw inore of the same, with three out of every five decisions calling forth multiple opinions. Frankfurter complamed to Rutledge near the end of the term about "an increasing tendency on the part of members of this Court to behave like little sclioolboys and throw spitballs at one another." 177 It is unclear whether he included himself in that description. When the Southern Conference for Human Welfare awarded Hugo Black its Jefferson Award in April 1945, Douglas, Murphy, Rutledge and Reed attended the ceremony; Frankfurter, Roberts, Jackson and the Chief Justice did not-one of the clearest examples of the demarcation within the Court.

The most shameful brouhaha came when Owen J. Roberts, weary of the contimuous infighting on the bench, resigned at the end of the 1944 Term. Although he and Frankfurter disagreed on certain issues of the law, they had found themselves temperamentally umited in their dishike of Douglas and Black, and what they viewed as the disastrous tendency of the "Axis" to overthrow the law. ${ }^{178}$ In his last full Term, Roberts dissented fifty-three times, or in almost one-third of the non-unanimous cases.

174. 321 U.S. at 113. Roberts also charged that the consequence of the majority strategy would be that "the administration of justice will fall into disrepute." Id. For editorial comment, see A. MASON, supra note 3, at 610-11.

175. Letter from E. M. Morgan to Felix Frankfurter (Feb. 10, 1942), quoted in A. MAsON, supra note 3 , at 589 .

176. Letter from Learned Hand to Felix Frankfurter (Feb. 6, 1944), Frankfurter Papers, Manuscript Division, Library of Congress, Washington, D.C.

177. S. Fine, supra note 12, at 244.

178. See From the DiARIEs of Felix Frankfurter, supra note 52, at 227, 229 (entries for April 20 \& 23, 1943). 
Following Court custom, Chief Justice Stone drafted a farewell letter which, in light of the Court's rancorous division, sounded a relatively neutral tone. Stone sent the letter to the senior Justice, Hugo Black, asking him to sign it and pass it on to the next most senior member of the Court. But Black objected to two phrases, one of which expressed the regret that the remaining brethren supposedly felt at Roberts' departure, and the other of which read: "You have made fidelity to principle your guide to decision." Black wanted to delete both these phrases. Stone reluctantly agreed to the deletions, but Frankfurter did not and protested. In the end, only Douglas agreed fully with Black's draft. ${ }^{179}$ Murphy, Reed and Rutledge were willing to sign either version in order to secure agreement, while Frankfurter and Jackson took an uncompromising stand and insisted on retaining the sentence on fidelity to principle. ${ }^{180}$ Neither side would budge, and as Alpheus T. Mason noted, "Emily Post would have disposed of the Justices' problem in a paragraph, ... . [b]ut etiquette was not the real issue."181 This "Lilliputian campaign, fought in dead earnest," 182 mirrored the pettniess and personal animosities which had come to mar the Court under Stone's stewardship.

\section{Justices AND Politics}

One issue which has been alluded to is Frankfurter's behef that Douglas either played pohtics on the Court, or intended to use the Court as a stepping-stone to high elected office. Although it is difficult, perhaps inıpossible, to appraise the truth of these charges (which Douglas later denied), one can document Frankfurter's growing suspicions, his behef in then1, and the bitterness they aroused.

It is clear that both Douglas and Frankfurter remained active pohtical participants well after joining the Court. Frankfurter's political activity, his role as Brandeis' surrogate, and his friendship and advisory relationship with Franklim Roosevelt, have been well documented. ${ }^{183}$ Douglas' political activity prior to 1939 was more open; as a member and then Chairman of the SEC he was expected to play the partisan game. Once he went onto the Court, he also contmued his political involvement

179. Compare Draft of suggested letter, showing Black's deletions, dated Aug. 20, 1945, with William O. Douglas' comment, dated Sept. 5, 1945, that these changes were "wholly agreeable" to him, Stone Papers, Manuscript Division, Library of Congress, Washington, D.C.

180. Letter from Felix Frankfurter to Brethren (Aug. 30, 1945), Stone Papers, Manuscript Division, Library of Congress, Washington, D.C. As usual, Frankfurter had to quote authority: "I know that that was Justice Brandeis' view of Roberts, whose character he held in the highest esteem." Id.

181. A. Mason, supra note 3, at 768 .

182. Id.

183. See B. MURPHY, supra note 29 , at $304-40$. 
but, like Frankfurter, in a more discreet inanner. Roosevelt's secretary, Grace Tully, recalled that four Justices often came to the White House on an off-the-record basis to consult at the President's request-Frankfurter, Douglas, Murphy and Jackson. ${ }^{184}$ When Roosevelt pondered a third term, he consulted with Frankfurter and Douglas, and both urged hin to run. ${ }^{185}$ Secretary of the Treasury Henry Morgenthau is known to have met with both Justices in May 1939 about proposed legislation that would have authorized wiretapping as a means to enforce certain laws; both men advised him against it. ${ }^{186}$ As one of Roosevelt's weekly poker buddies, Douglas also had occasion to talk to Roosevelt on policy items, and he discussed such matters as desegregation of the armed forces and relations with Russia, and occasionally lent a hand, as he had done before 1939, to drafting the President's speeches. ${ }^{187}$

In a diary entry for April 27, 1943, Frankfurter claims to have told Roberts that

not long after Douglas came on the Court it was as plain as a pikestaff to me that he was not consecrated to the work of this Court but his thoughts and ambitions were outside it. And for me such ambition in a man corrupts his whole nature--especially if he is a judge .... ${ }^{188}$

In fact, there had been speculation outside the Court about Douglas' pohtical future almost from the time of his appointment, and his name figured prominently as a potential candidate in the elections of 1940, 1944 and 1948. In a letter written to Frankfurter just prior to the 1940 Democratic convention, Douglas wrote:

There is considerable talk in Washington about putting me on the ticket. I discount it very much. ... But it is sufficiently active to be disturbing. It is disturbing because I want none of it. I want to stay where I am. This line to you is to ask you, should the matter come your way, to scotch it. You need not be told any reasons. You know hosts of them-from the ones Brandeis would give, on down. I an most serious about this-probably more serious than the possibilities justify. ${ }^{189}$

There is hittle to suggest that Douglas did not mean what he said at the time, but he was too politically acute not to liave been aware of the talk among Democratic leaders about his youth, his liberal record, his west-

184. From the Diaries of Felix Frankfurter, supra note 52, at 77.

185. Id.

186. B. MURPHY, supra note 29 , at 228.

187. Id. at 255 (citing Time, Mar. 10, 1941); see also W. Douglas, supra note 30, at 332-33.

188. From the Diaries of FeliX Frankfurter, supra note 52, at 230.

189. Letter from William O. Douglas to Felix Frankfurter (July 2, 1940), Douglas Papers, Manuscript Division, Library of Congress, Washington, D.C.; see also Letter from William O. Douglas to Harlan F. Stone (Aug. 21, 1940), Stone Papers, Manuscript Division, Library of Congress, Washington, D.C. 
ern roots and open manner balanced by an eastern education and a powerful intellect. He must also have known that people like Tommy Corcoran, Harry Hopkins and Harold Ickes were promoting him for the vice presidential spot. ${ }^{190}$ It is likely that if Roosevelt had asked him to go on the ticket, Douglas would have agreed, just as he did in 1941 when Roosevelt apparently asked Douglas to head the War Production Board. ${ }^{191}$ Douglas never made any public statements of either his intent to stay on the Court or that he might leave. It seens clear that on several occasions he had a divided mind on the subject, for if he had really wanted to take his naine out of consideration, the person he should have notified was Franklin Roosevelt and not Felix Frankfurter. ${ }^{192}$

Whether Frankfurter did, in fact, suspect Douglas froin the start, he did attribute changes in Douglas' votes-as in Barnette-as well as the wording of soine of Douglas' opmions, to political reasons. By 1943 he believed others on the bench also expected Douglas to enter active pohtics, and recorded an interesting conversation he claimed took place with Frank Murpliy:

FF: How many plugged nickels would you give for Bill Douglas' chance of becoming President?

FM: Well, I think all the other contenders for the nomination will kill themselves off and that will leave only Bill.

FF: I didn't ask you for his chances to become a candidate but his chances to become President.

FM: Well, no Democrat will be elected in '44; but Bill will be named, I believe. I am only sorry that $\mathrm{m}$ order to gain what he beheves to be the Catholic vote, the financial end of his campaign is being managed by Joe Kennedy and Johnnie Burns, and Brandon and Paul Shields. But he will $\mathrm{mn}$ in such a vay as to make hinself available the next time thereafter.

FF: I am surprised, Frank, that it doesn't shock you to have this Court made a jumping-off place for politics.

FM: Well, I don't like it.

FF: Well, it's much more than a matter of not liking. When a priest enters a monastery, he must leave-or ought to leave-all sorts of worldly desires behmd him. And this Court has no excuse for being unless it's a monastery. And this isn't idle, high-flown talk. We are all poor human creatures and it's difficult enough to be wholly intellectually and morally disinterested when one has no other motive except that of being a judge aceorcling to one's full conscience. And the returns are all in on judges of this Court who, while on the Court, have had conflicting political ainbitions. We know all the instances and the

190. See J. Simon, supra note 21, at 260.

191. Letter from William O. Douglas to Hugo Black (Sept. 8, 1941), Black Papers, Manuscript Division, Library of Congress, Washington, D.C.; W. Douglas, supra note 47, at 268.

192. J. SimoN, supra note 21, ch. 20. 
experience is unedifying and disastrous. ${ }^{193}$

Even the naive Roberts recognized Douglas' political ambitions, according to Frankfurter, and when Roosevelt indicated his willingness to take Douglas as his running inate in 1944, all of Frankfurter's suspicions seeined confirmed. 194

Douglas' name came up for consideration again froin 1946 to 1948, and in fact, Harry Truinan did offer Douglas the vice presidential nomination in 1948. Douglas turned him down, ${ }^{195}$ but it is difficult to know whetlier he did so because he really wanted to stay on the Court or, as soine have suggested, because he thiought Truman had no chance of winning. ${ }^{196}$ During these two years, Frankfurter's carping about Douglas' alleged anbitions continued. ${ }^{197}$ When both Douglas and Chief Justice Fred Vinson were inentioned as potential candidates, Frankfurter wrote in exasperation to Charles Burlingham that " $[n]$ othing is inore important than for every inember of the Court to put all other thoughts, than law and Court, out of his consciousness . . ." 198

Frankfurter's sanctimonious preaching might have been inore convincing if we did not know that he himself, even after he had entered the inonastery, never cut himself off froin political life while Franklin Roosevelt lived, and retreated-reluctantly-only after lie realized that he had no influence over Harry Truman. Moreover, his colleagnes knew about Frankfurter's involvement, his behind-the-scenes nianipulation; Chief Justice Stone complained that Frankfurter was "getting out of scale."199 Douglas, near the end of his life, contrasted himself with Frankfurter. "I took my advice from Justice Brandeis," lie told Janies Simon. "We spoke about it. He told nie that a nieniber of the Court could not have political ambitions because it would hurt the Court. I didn't. But Felix did. He tried to run Bob Jackson for the presi-

193. From the Diaries of Felix Frankfurter, supra note 52, at 155 (entry for Jan. 1 , 1943).

194. The full story can be found in J. Simon, supra note 21, at 262-66. See also Letter from Felix Frankfurter to Marion Frankfurter (Sept. 14, 1944), reprinted in H. HIRSCH, supra note 38, at 178. But see Letter from William O. Douglas to F.T. Maloney (Jan. 14, 1944), Douglas Papers, Manuscript Division, Library of Congress, Washington, D.C.

195. Letter froin William O. Douglas to President Truman (July 31, 1948), Douglas Papers, Manuscript Division, Library of Congress, Washington, D.C.; see also W. DougLAS, supra note 47, at $288-90$.

196. J. SiMON, supra note 21, at 274.

197. From the Diaries of FELIX Frankfurter, supra note 52, at 301, 338, 339, 341 (entries for Nov. 19, 1946, Dec. 30, 1947, Jan. 16, 1948, and Jan. 19, 1948).

198. Letter from Felix Frankfurter to Charles C. Burlingham (June 24, 1946), quoted in B. MURPHY, supra note 29, at 261.

199. From the Diaries of Felix Frankfurter, supra note 52, at 76; see G. White, EarL WARREN: A PUBLIC LIFE 176 (1982). 
dency."200 One need not take Douglas' words at face value any more than Justice Frankfurter's posturings. ${ }^{201}$ Douglas had had a meteoric rise-Sterling Professor at Yale at thirty-two, chairman of the SEC at thirty-eight, confidant of the President and Associate Justice of the United States Supreme Court at forty. It had been so fast, even Douglas thought himself too young to go on the bench. It is true that Douglas could easily have taken himself out of the race in 1940 and 1944 by directly informing the President, as he did in 1948, and it is probably true that he had mixed enotions, political ambition striving against the ideal which Frankfurter so eloquently and so hypocritically expressed. But one might also question the prospect of a Justice publicly announcing his unavailability for elective office when appointment to the Court implicitly carried that understanding. Douglas did write to Stone, he did make himself physically unavailable, he did tell close friends that he would not accept a noinination. Moreover, despite Frankfurter's snide comments about the political rationale for Douglas' switch in the flag-salute cases, a politically astute person would hardly chanipion the cause of an unpopular and seemingly unpatriotic mmority during wartime!

One should also note the personal loyalty that both Douglas and Frankfurter had to Franklin Roosevelt. Had the President directly asked Douglas to run with him in 1940 or 1944, Douglas probably would have accepted, just as he agreed to head the WPB in 1942 if Roosevelt wanted him. To have served with Roosevelt, whom he so greatly admired and to whom he owed so nuch, would have been attractive to him. Joseph Lash also suggested that at least part of the discord between the two Justices resulted front their rivalry for Roosevelt's affections. ${ }^{202}$ Frankfurter had known him longer, yet Douglas offered Roosevelt a chummy, down-to-earth companionship, totally different from Frankfurter's highly intellectual and at times importuning advice. ${ }^{203}$ Douglas told good stories and played a fair game of poker, a game Frankfurter tried to learn but never could. One should not attribute too much to this conscious or subconscious "rivalry," but it is one more piece in the mosaic of the Court's history of these years.

200. J. SiMON, supra note 21 , at 9.

201. See The Douglas LetTers ch. 8 (M. Urofsky \& P. Urofsky eds. 1987) (describing Douglas' constant efforts to get people appointed to government offices, advice to John Kenncdy and Lyndon Johnson, and other political activities).

202. From the Diaries of Felix Frankfurter, supra note 52, at 77.

203. See H. HiRSCH, supra note 38 , at 178 . 


\section{ViII. Playing Out the Scenario}

The story from 1946, with the death of Stone, to 1962, when a stroke forced Frankfurter to retire, is for the most part a playing out of the same scenario, with a few dramatic inoinents but no major changes in the script. Frankfurter won his last major battle in Adamson v. California, ${ }^{204}$ when he gathered a bare majority to hold that the fourteenth amendment did not incorporate the first eight amendments and make them fully apphicable to the states, a reiteration of the position expressed by Justice Cardozo a decade earher in Palko v. Connecticut. ${ }^{205}$ Although he won the battle, he lost the war. The Court has never fully endorsed the Black/Douglas view of total incorporation, but it has apphed nearly the full spread of protections against the states.

A major shift within the Court came with the appointment of Earl Warren as Chief Justice in 1953, and with William J. Brennan as Associate Justice three years later. At first Frankfurter expressed great enthusiasm for Warren, whom he believed a clever politician (and who could, therefore, protect the Court as Taft and Hughes had done), but somewhat weak in the law, and thus open to his tutelage. Frankfurter, never seeming to learn or to stop hoping, repeated the same pattern of flattery, attention, cajoling, and endless attempts at instruction, but it did no good. As Warren grew accustomed to the Court, he relied more on his own judgment and began to resent Frankfurter's constant stream of advice. ${ }^{206}$ The new Chief moved within three years from a centrist position in the Court's makeup to alignment with the liberal wing, ${ }^{207}$ and for this he earned Frankfurter's condemnation. In a letter to Learned Hand in 1957, a bitter Frankfurter lumped Warren with Black and Douglas as men "whose "common denommator is a self-willed self-righteous powerlust," " men " 'undisciplined by adequate professional learning and cultivated understanding' . . . who made decisions on the basis of 'their prejudices and their respective pasts and self-concious desires to join Thomas Paine and T. Jefferson in the Valhalla of "liberty" and in the ineantime to have the avant-garde of the Yale Law School . . . praise them.' "208

204. 332 U.S. 46 (1947).

205. 302 U.S. 319 (1937); see also W. DougLAS, supra note 47, at 53.

206. G. WHrre, supra note 199 , at 179.

207. Jacobs, The Warren Court-After Three Terms, 9 W. PoL'y Q. 937 (1956).

208. G. WHITE, supra note 199, at 181 (quoting letter from Felix Frankfurter to Learned Hand (June 30, 1957)). Interestingly enough, Frankfurter's hero, Louis D. Brandeis, was a great admirer of Jefferson. After a visit to Monticello, Brandeis wrote to Frankfurter: "I have spent a day at Charlottesville to see Monticello \& the University. It is strong confirmation that T.J. was greatly civilized. Washington, Jefferson, Franklin, Hamilton were indeed a Big Four." Letter from Louis 
As the years passed, the antagonism between the two men and the forms it took remind an observer not of two distinguished menibers of the nation's highest tribunal, but of two third graders seeing how spiteful they could be to each other. In his memoirs Douglas denied as "apocryphal" a story that after Franlfurter asked a question, a lipreader in the courtrooin claimed that Douglas said to his neighbor: "Why doesn't the son of a bitch keep his mouth sliut?"209 But there are documented instances of Douglas calling his colleague "Der Fuehrer," the "little bastard," "the Little Giant,"210 "Machiavellian," "divisive,"211 and a "prevaricator." 212 Frankfurter: could be, as we liave seen, equally caustic, calling Douglas "malignant,"213 "narrow minded,"214 "the most cynical, slianelessly amoral cliaracter I've ever known,"215 and a "mommser" [bastard].216

If Frankfurter's long diatribes in the form of lectures irked Douglas, the latter knew how to irritate Frankfurter as well. In 1960, during oral arguinent, Frankfurter was hectoring counsel and after each question, Douglas would lean forward with a helpful answer. Fimally Frankfurter snapped at the lawyer "I thought you were arguing this case." "I am," the attorney replied, "but I can use all the help I can get."217

In 1957, the Court reviewed a Los Angeles ordinance requiring registration with the police of any person previously " convicted of an offense punishable as a felony in the State of California." "218 In conference all the bretliren agreed that the ordinance failed as vague and arbitrary, and Warren assigned the opinion to Douglas. His draft focused on the phrase "punishable as a felony," and only Black agreed that the phrase itself was too vague. Douglas redrafted the opinion to reflect the majority view that due process liad been violated when registration was re-

Brandeis to Felix Frankfurter (Sept. 22, 1927), Frankfurter Papers, Manuscript Division, Library of Congress, Washington, D.C.

209. W. Dovglas, supra note 47, at 22.

210. S. FINE, supra note 12 , at 254.

211. J. Simon, supra note 21 , at 9.

212. W. Douglas, supra note 30 , at 327.

213. From the Diaries of Felix Frankfurter, supra note 52, at 343 (entry for Mar. 9, 1948).

214. Letter from Felix Frankfurter to Learned Hand (Feb. 13, 1958), Frankfurter Papers, Manuscript Division, Library of Congress, Washington, D.C.

215. Letter from Felix Frankfurter to Learned Hand (Nov. 5, 1954), quoted in B. MURPHY, supra note 29 , at 268 .

216. Letter from Felix Frankfurter to H. Laski (July 27, 1949), Frankfurter Papers, Manuscript Division, Library of Congress, Washington, D.C.

217. B. SchWARTZ, supra note 44, at 306 (quoting N.Y. Times, June 11, 1961, § VI, at 31) (emphasis added).

218. Lambert v. California, 355 U.S. 225, 226 (1957). 
quired of persons who had no knowledge of their duty to register. ${ }^{219}$

This still carried five votes, but Frankfurter, joined by Harlan and Whittaker, dissented, as did Harold Burton separately. Frankfurter delivered his dissent on 16 Deceinber, and as Douglas told Black:

[O]ur friend from Harvard . . . went hogwild. He said it would take a book to list all the criminal statutes which this decision held unconstitutional. Therefore, he did not want to clutter up the law books with all these hundreds or thousands of citations.

Since the announcement of his dissent, I have been writing him asking him to give us just one citation of one other statute which would be held unconstitutional.

It is now 11:40 AM, December 17th, and this has been going on for nearly 24 hours. He has not yet sent me any citations, but if he does I will rush it all down to you, because I know you must be as worried about the devastating effect of Lambert ... as I am..$^{220}$

Frankfurter could not produce a single citation, ${ }^{221}$ and even denied making the comment, but Douglas would not let go, and the two men exchanged several notes that day.222 Frankfurter's anger at the decision is undeniable; in his written dissent he wrote: "I feel confident that the present decision will turn out to be an isolated deviation from the strong current of precedents-a derelict on the waters of the law."223

Even when Frankfurter had constructive comments to inake, his didactic manner rubbed the brethren the wrong way, especially Douglas. For example, as Dennis Hutchinson has shown, 224 Frankfurter began making suggestions for improving and strengthening Court procedures around 1950, and at the beginning of every term would circulate a lengthy menioranduin enumerating and explaining his proposed changes. One can recognize in one section of the 1956 Term meinorandum all the irritating features discussed above:

Even before I came on the Court, I had good reason to believe that the course of proceedings leading to adjudication was not all that it might be. My grounds for feeling that the deliberative process was inadequate derived from the imtimacies I had enjoyed over the years with

219. Id. at $227-30$.

220. Letter from William O. Douglas to Hugo Black (Dec. 17, 1957), Douglas Papers, Manuscript Division, Library of Congress, Washington, D.C.

221. In fact, the dissent is curiously devoid of authority. Frankfurter normally crammed his opinions with copious references to precedent as well as other sources. His dissent in Lambert cites only one case, United States v. Balint, 258 U.S. 250 (1922), only for a quote on the police power and a passage froin O.W. Holmes, THE COMMON LAw 50 (1881).

222. For a sample of these notes, see THE Douglas LetTERS, supra note 201, at 86-88. See also B. SchwaRTZ, supra note 44, at 307-09.

223. 355 U.S. at 232. In fact, Lambert was never overturned by subsequent Courts. Occasionally Douglas' barbs backfired. See B. SchwarTz, supra note 44, at 360-61 (Douglas wrote apology to Frankfurter when one of Douglas' barbs was taken seriously).

224. Hutchinson, supra note 31 , at 144-45. 
Justices Holmes, Brandeis, and Cardozo.225

In his "October greeting" for the 1960 Term, he suggested several ways he thought would improve and speed up the voting and announcement procedures. In particular he wanted the per curiam decisions issued iminediately, rather than allowing a single Justice to hold up the announceinent if he wanted to think about it soine inore; Frankfurter then asked for a conference to discuss his proposals. Douglas had his answer printed and circulated:

With all due respect, I vote against a meeting to discuss the proposals. The virtue of our present procedures is that they are very flexible. If any one wants a per curiam held over, it is always held. If anyone wants to pass and not vote on a case until a later Conference, his wish is always respected. If anyone wants to circulate a memo stating his views on a case, the meno is always welcome.

If we unanimously adopted rules on such matters we would be plagued by them, bogged down, and interminably delayed. If we were not unanimous, the rules would be ineffective. I, for one, could not agree to give anyone any more control over when I vote than over how I vote. ... We need not put ourselves in the needless harness that is proposed. 226

When Frankfurter renewed the suggestion the following year, Douglas expressed his continued opposition, and in even stronger terms:

We are not first-year law students who need to be put under strict restraints. ... The blowing of whistles, the counting to three or ten, the suspension of all activity for a stated time may be desirable and necessary on playgrounds or in sports. But we are not children; we deal not with trivia; we are not engaged in contests. Our tasks involve deliberation, refiection, meditation. ... When opimions have jelled, the case is handed down. When jelling is not finished, the case is held.227

There were, as Professor: Hutchinson notes, a number of worthwhile ideas in these annual ineinoranda, but Frankfurter's abrasiveness often prevented a fair hearing. Moreover, Frankfurter himself often held up decisions for weeks and even months as he laboriously prepared his elaborate opinions. At the end of the 1948 Term, Douglas (who always wrote quickly) had been the one to coinplain about delays, and had suggested that a case be reassigned if a Justice held up his opinion more than three inonths after the case had been decided at Conference. "I do not think," he told the brethren, "in fairness to each other and the litigants, one of us [Frankfurter] should be allowed to serve his own personal ends

225. Id. at $182-83$.

226. William O. Douglas, Memorandum to Conference (Oct. 13, 1960), Douglas Papers, Manuscript Division, Library of Congress, Washington, D.C.

227. William O. Douglas, Memorandum to Conference (Oct. 23, 1961), Douglas Papers, Manuscript Division, Library of Congress, Washington, D.C. 
by holding cases beyond that time."228

One imight also note that once again Frankfurter, who so prided himself on understanding the importance of personal relations and individuatity on the Court, so imisjudged the issue. His proposal can be seen as part of his einphasis on procedure, on getting the rules and the process right, in the behef that right procedure always will produce the right result. Douglas' chilly response is undoubtedly correct, in that the nature of judging could not always be girdled by rules, that there had to be room for flexibility, for the accommodation of a Justice's second thoughts, of a desire to rethink and perhaps rediscuss a difficult issue rather than rushing to judginent because of an artificially imposed time himit.

By the time of this exchange, both men had given up any pretense at civility toward each other beyond the absolute bare minimum required to sit in the saine court room and conference. Frankfurter, as he often did, unburdened his frustrations in a letter to Learned Hand:

If I gave you a bill of particulars of what I have hived through in these now nearly twenty years, even you with all your knowledge and discernment would realize that you don't know nuthin'. "I could unto you a tale unfold" that would shock you, hardened character that you are. ${ }^{229}$

The judicial process engaged in by Black and Douglas, he charged, "would have warranted Cardozo to say about the civil hiberties cases, as he said about cases involving economic issues in his time, " $[t]$ his is not a court of law." "230

Things did get worse, however, shortly after the mitial exchange of meinoranda on Frankfurter's per curiam proposals, which the brethren rejected. On November 23, 1960, Douglas drafted a inemorandun of his own, which he evidently did not send after discussing the matter with Chief Justice Warren. In it he wrote:

The continuous violent outbursts against me in Conference by my Brother Frankfurter give me great concern. They do not bother ine. For I have been on the hustings too long.

But he's an ill man; and these violent outbursts create a fear in iny heart that one of them may be his end.

I do not consciously do anything to annoy him. But twenty-odd years have shown that I am a disturbing symbol in his life. His outbursts against me are increasing in intensity. In the interest of his

228. William O. Douglas, Memorandum to Conference (June 15, 1949), quoted in S. FINE, supra note 12 , at 254 .

229. Letter from Felix Frankfurter to Learned Hand (June 30, 1957), Frankfurter Papers, Manuscript Division, Library of Congress, Washington, D.C.

230. Id. 
health and long life I have reluctantly concluded to participate in no more conferences while he is on the Court.

For the cert hists I will leave my vote. On argued cases I will leave a short summary of my views. ${ }^{231}$

It was, of course, impossible for any member of the Court to isolate himself from another member, no matter how tense their relationship, and the Douglas files include some short notes between the two men over the next two years, imdicating a joining in opimions and occasionally making some brief suggestions.

Douglas' ineinoirs tend to play down the personal differences between the two men, and to emphasize their doctrinal disagreements. The story that "Frankfurter and I were enemies," he declared, "was not the case. Although we differed greatly on the merits of many cases, we were not enemies."232 In 1974, Douglas responded to an inquiry from Professor David Atkinson regarding an alleged outburst between Frankfurter and Douglas at conference in May 1954, during discussion of two related Interstate Coinmerce Commission cases. ${ }^{233}$ Shortly after the conference, Douglas wrote an angry note to Frankfurter:

Today at Conference I asked you a question concerning your inemoranduin opinion .... The question was not answered. An answer was refused, rather insolently. This was so far as I recall the first time one member of the Conference refused to answer another neinber on a matter of Court business.

We all know what a great burden your long discourses are. So I am not complaining. But I do register a protest at your degradation of the Conference and its deliberations. ${ }^{234}$

Twenty years later Douglas claimed to have no recollection of the episode, "so it could not have been very critical or important." Then he went on in the following vein:

We were always twitting our Brother Frankfurter over his long and drainatic performances in Conference. He was an artist as well as an able advocate and his Conference presentations were dramatic and lengthy. Most of us thought the function of the Conference was to discover the consensus. His idea was different: he was there to prosletyze and to gain converts. ...

231. William O. Douglas, Memorandum to Conference (Nov. 23, 1960), Douglas Papers, Manuscript Division, Library of Congress, Washington, D.C.

232. W. Douglas, supra note 47 , at 43.

233. Secretary of Agric. v. United States, 347 U.S. 645 (1954) (decided together with Florida Citrus Comm'n v. United States). Frankfurter, for a five-member majority, upheld an ICC ruling; Douglas dissented, joined by Black and Warren. Id. at 655.

234. Memorandum from William O. Douglas to Felix Frankfurter (May 29, 1954), Douglas Papers, Manuscript Division, Library of Congress, Washington, D.C. 
One would err greatly to conclude that Frankfurter and I were at war. We clashed often at the ideological level but our personal relations were excellent and I always enjoyed being with him. ${ }^{235}$

Whatever truth one wishes to attribute to this expression of devotion, Douglas did pay tribute to Frankfurter on occasion. He placed him on his "All-American team" for the Court, chosen from the twenty-nine men with whom he served on the Court during his record thirty-six year tenure, along with Black, William Brennan and Ear1 Warren.236 Shortly before his death, Douglas told James Simon that "Felix belonged on this Court. He knew constitutional history and he knew this Court. He was a brilliant advocate of his conservative philosophy."237

\section{CONCLUSION}

There would have been some tension under the best of circumstances between Mr. Justice Frankfurter and Mr. Justice Douglas. Each had great intellectual capacity, an imdependent spirit, and a strong egoa guaranteed recipe for conflict. Moreover, each strongly espoused a doctrine of constitutional interpretation directly contrary to that held by the other. Frankfurter personified to both friend and foe the theory of judicial restramt, while Douglas and Black stood for judicial activism. "My view always has been," Douglas explained, "that anyone whose life, liberty or property was threatened or impaired by any branch of government ... had a justiciable controversy and could properly repair to a judicial tribunal for vimdication of his rights."238 Frankfurter could not have disagreed more.

Other Justices, however, holding equally strong views, have managed to remain on civil and even cordial terms with colleagues adhering to diametrically opposite opinions. With the exception of the anti-semitic McReynolds, Brandeis got along well witl the conservatives who dominated the Court during most of his twenty-three year tenure. On today's Court, Chief Justice Rehnquist and Justice Brennan could not be further apart doctrmally, yet apparently manage to get along quite well. I am no partisan of William O. Douglas as a person-he could be and often was petty, mean-spirited and arrogant-but he had far better relations witl every other Justices he served with than' with Frankfurter. ${ }^{239}$

235. The Douglas LetTers, supra note 201, at 97-98 (emphasis added).

236. W. Douglas, supra note 47 , at 42.

237. J. Simon, supra note 21, at 8-9. Douglas then deflated the portrait by adding: "Felix always insisted that people be subservieut to him. Even when he was at Harvard and I was at Yale, he treated everybody, even his colleagues, like his studeuts. . . . He was a divisive influence, even before he came to the Court. Everywhere he was, he was divisive . . . " Id. at 9.

238. W. Douglas, supra note 47 , at 55.

239. See the sample of letters in The DOUglas LeTtERS, supra note 201, ch. 5. 
Frankfurter, on the other hand, for all that he could be charming, solicitous, witty and outgoing, was also duphicitous and conniving, and as we have seen, these characteristics triggered confrontation.

As friend and foe noted, Frankfurter tended to divide the world into disciples and inentors. While possibly an appropriate attitude for a professor, it boded ill when he had to deal with persons who did not care to be treated as students. This had led to a break between Frankfurter and two of his most gifted proteges, Ben Cohen and Thomas Corcoran, who after seven years of doing top-level work for the President of the United States, refused to be treated any inore as two of Frankfurter's brighter students. "Felix is incapable of having adult relationships!" Cohen coinplained; Frankfurter could relate well to his mentors and his students, but not to his peers. 240

It may be that Frankfurter's success as a professor spoiled him for his work as a Justice. He did, as Douglas noted, know inore about the Court than anyone else, he had been on intimate terms with Holmes, Brandeis and Cardozo, and he therefore assumed that he had some special knowledge denied to others, even to those who sat on the bench. He could not understand why his colleagues resented his efforts to share witl them, to instruct thein, in this knowledge; he saw it as his duty to instruct, just as it had been while he liad been at Harvard. This not only generated resentment, but gave Douglas a sympathetic audience for his barbs at Frankfurter's poinpous arrogance.

Unfortunately, Frankfurter's intellectual arrogance, combined witlı a nastiness soine of his students had seen years earhier, ${ }^{241}$ led him to alienate nearly all of his colleagues at one time or another. He would flatter them so long as they agreed with him, but at the first sign of independent thouglit he would explode. Durmg his tenure on the bench, no one-with the possible exception of Robert Jackson-escaped his scorn. Typical are the comments he scribbled on an opimion by Wiley Rutledge that went against his advice: "[I]f $I$ had to expose all your fallacies I would have to write a short book on (1) federal jurisdiction (2) constitutional law (3) procedure generally."242

Frankfurter's high-flown lectures on the purity of the Court often angered those who saw the hypocrisy-for there is no other word for itin his secretive political activities at the same time that he damned Douglas for allegedly desecrating the temple. Further, his loudly proclaimed adherence to judicial restraint did not hide from either the bench or the

240. B. MURPHY, supra note 29, at 191.

241. M. PARRISH, supra note 31.

242. Letter to Wiley Rutledge (Feb. 8, 1947), quoted in S. FiNE, supra note 12, at 255. 
law reviews the fact that he wrote his own views into opinions just as much as the "Axis." Douglas was not alone in describing Frankfurter as "a real conservative who einbraced old precedents under the guise of bowing to 'the law,' but who actively chose the old precedents because he liked thein better." 243

Frankfurter and Douglas were both passionate nien who believed strongly in their principles. Justices of the Suprenie Court, as we well know, do not give up their emotions and prejudices when they don the black robe, although we do expect them to keep private feelings somewhat in check. For all his constant reference to Holnes and Brandeis, Frankfurter could never separate his judicial from his private views as they did. He personalized every battle, so that within five years of going on the bench he divided his brethren into "we" and "they"-allies and enemies. Douglas did so too, but to a far lesser and less objectionable degree. He cared hittle about building a majority, and so his letters and notes to the brethren lack the personalized diatribes that run througliout the Frankfurter diaries. ${ }^{244}$ If people voted witl Douglas, well and good; if not, they were probably wrong, but that was their problem, not his. Given the bitterness that poisoned Frankfurter's years on the bench, it is hard not to beheve that Douglas had the better attitude.

From early on both men saw themselves as alligned on opposing sides of a great constitutional divide. Frankfurter consciously claimed the leadership of the faction devoted to the philosopliy of judicial restraint as he espoused it; Douglas deferred to Hugo Black's leadership, but in the minds of Frankfurter and of the public, the two stood together for judicial activism, especially in the area of Bill of Riglits protection. Both believed in their causes, and as a result, may have gone to extrennes whicl,, witlout the constraining force of the other, could well have proved detrimental to the country. Constitutional vitality requires a Court sensitive to its limitations, yet also willing to chart new areas of law as the times and the nation's needs change. It is possible that the country-and the Constitution-benefitted from the philosophical tensions and debates generated by the clash of the views between Frankfurter and Douglas. Unfortunately, the Court and its members suffered for more than two decades froin the personal animosities of these two prima donnas of the law.

243. W. Douglas, supra note 30, at 243; see also Hamilton, Book Review, 56 YALE L.J. 1458, $1459-60$ (1947).

244. The Douglas Letters, supra note 201, Part II. 